\title{
Increasing intake of essential fatty acids from milk replacer benefits performance, immune responses, and health of preweaned Holstein calves
}

\author{
M. Garcia, ${ }^{*}$ J. H. Shin, ${ }^{*}$ A. Schlaefli, ${ }^{*}$ L. F. Greco, ${ }^{*}$ F. P. Maunsell,† W. W. Thatcher, J. E. P. Santos, \\ and C. R. Staples*1 \\ *Department of Animal Sciences, University of Florida, Gainesville 32608 \\ †College of Veterinary Medicine, University of Florida, Gainesville 32610
}

\begin{abstract}
The objective was to evaluate the effect of feeding increasing amounts of essential fatty acids (FA) in milk replacer (MR) during the first $60 \mathrm{~d}$ of life on growth, health, and immunity of Holstein calves. Calves were born from dams fed low concentrations of total and essential FA during the last 2 mo of pregnancy. Newborn calves were blocked by sex and parity of the dam and assigned randomly to receive 1 of $4 \mathrm{MR}$ treatments (T). Hydrogenated coconut oil and soybean oil were mixed with emulsifier and commercial MR powder to prepare the following $4 \mathrm{MR}$ containing 0.119 and 0.007 (T1), 0.187 and 0.017 (T2), 0.321 and 0.036 (T3), and 0.593 and $0.076(\mathrm{~T} 4) \mathrm{g}$ of intake per $\mathrm{kg}$ of metabolic body weight $\left(\mathrm{BW}^{0.75}\right)$ of linoleic acid and $\alpha$-linolenic acid, respectively. At $30 \mathrm{~d}$ of life, concentrations of essential FA (linoleic acid and $\alpha$-linolenic acid) in liver increased, whereas concentrations of $\mathrm{C} 12: 0, \mathrm{C} 14: 0, \mathrm{C} 16: 0$, and C20:3n-9 decreased linearly with increasing intake of essential FA. Body weight gain and feed efficiency were optimized when male calves consumed T2, whereas gain by female calves tended to increase linearly with increasing intake of essential FA during the first $30 \mathrm{~d}$ of age. However, these responses to treatment were not maintained after initiation of concentrate feeding at $31 \mathrm{~d}$ of life. Over the 60-d preweaning period, wither and hip heights were improved in both sexes as intake of essential FA increased up to T3. Some measures of health and immunity were affected by replacing some coconut oil with soybean oil. Severity of diarrhea tended to decrease linearly; plasma concentrations of haptoglobin during diarrhea were lower in T2, T3, and T4; phagocytosis by blood neutrophils tended to peak for calves fed T2; in vitro proliferation of stimulated blood lymphocytes was greater for calves fed $\mathrm{T} 2$; in vitro stimulated blood cells produced more IFN- $\gamma$ (up to T3 for males and T2 for females), concentrations of
\end{abstract}

Received May 19, 2014.

Accepted September 23, 2014.

${ }^{1}$ Corresponding author: chasstap@ufl.edu serum IgG against ovalbumin injections were increased in males fed T2 or T3; and skin-fold thickness increased in response to an intradermal antigen injection of all calves fed up to T4. Across sex and under the conditions of the present study, mean daily intakes of linoleic acid between 3 to $5 \mathrm{~g} / \mathrm{d}$ and intakes of $\alpha$-linolenic acid between 0.3 and $0.6 \mathrm{~g} / \mathrm{d}$ during the first $30 \mathrm{~d}$ of life promoted growth of preweaned Holstein calves, possibly by improving their immune status.

Key words: calf, essential fatty acids, growth, immunity

\section{INTRODUCTION}

Attainment of good growth and health during the preweaning period is the main goal of those rearing dairy calves, as excess morbidity and mortality can significantly affect profit. Compared with that of other species, the immune system of calves is immature in early life (Godden, 2008). Calves must rely on their innate immune system for protection against initial pathogens as their adaptive immunity system develops (Chase et al., 2008). Dietary provision of the correct amounts of essential nutrients is beneficial to the growth and health of newborn calves. Linoleic acid, first identified as an essential nutrient for rats fed fat-free diets (Burr and Burr, 1930), should be beneficial to newborn calves but research to document this is lacking. Those authors identified poor growth, dermatitis, poor reproduction, and death as symptoms of long-term linoleic acid deficiency in rats suffering from "low fat disease." Much later, $\alpha$-linolenic acid was identified as an essential FA by the role of its derivative, docosahexaenoic acid (DHA; C22:6n-3), in brain development using specific tests of retinal and brain function in monkeys and rats (Neuringer et al., 1988; Anderson and Connor, 1989).

Supplementing milk replacer (MR) with different sources of FA improved the growth of preweaned calves (Jenkins et al., 1985, 1986; Jenkins and Kramer, 1986). However, for those studies, classical symptoms of an essential FA deficiency (e.g., poor growth, dermatitis, death) were not detected as reported by others feeding fat-free diets to preweaned ruminants (Cunningham 
and Loosli, 1954; Lambert et al., 1954). Moreover, feeding lower amounts of linoleic acid caused an immediate decline in concentrations of linoleic acid in plasma and erythrocytes of rats but an increase in that of preruminant calves, indicating that calves may have a lower dietary requirement, a greater efficiency of conservation, or a greater ability to mobilize linoleic acid from adipose tissue (Sklan et al., 1972). These ruminant studies used only growth, incidence of diarrhea, and FA profile of plasma and tissue, including the ratio of $\mathrm{C} 20: 3 \mathrm{n}-9$ to $\mathrm{C} 20: 4 \mathrm{n}-6$, to assess calf responses to dietary fats. Efforts should be made to establish FA intakes that optimize animal health, rather than identifying minimal amounts that are sufficient only for growth (Cunnane and Guesnet, 2011). Therefore, metabolic profile, severity of diseases, and measures of immune function should be considered in assessment of essential FA deficiency.

Several studies, performed primarily in rodents, have verified that the FA profile of the phospholipid fraction of immune cells reflects that of the diet and also that changes in proportions of n- 6 and n- 3 FA can modify the function of immune cells (Calder, 2008). Consuming sufficient amounts of linoleic acid should help the acute inflammatory response of the calf when exposed to environmental pathogens because linoleic acid serves as a precursor of proinflammatory mediators such as cytokines and eicosanoids (Calder, 2006). These compounds contribute to the activity of the all-important innate immune cells, such as monocytes and neutrophils in the early weeks of life. However, an exacerbated proinflammatory condition could impair calf health. The antiinflammatory properties of $n-3$ FA such as $\alpha$-linolenic acid may aid in the resolution of inflammation by reducing the activity of signaling molecules and the expression of proinflammatory genes (Schmitz and Ecker, 2008). Therefore, it is critical to identify the symptoms of impaired metabolic, immune, and inflammatory processes associated with reduced intakes of essential FA to help determine actual dietary requirements.

Recent studies (Ballou and DePeters, 2008; Ballou et al., 2008) have focused on the effect of dietary n-3 FA on growth and markers of immune responses of preweaned dairy calves, whereas similar research involving n-6 FA is lacking. Hence, the hypothesis of the current study was that increasing intakes of linoleic acid and $\alpha$-linolenic acid would improve immune responses of unweaned Holstein calves and, therefore, positively affect overall calf performance. The objective was to evaluate the effect of feeding increasing amounts of linoleic and $\alpha$-linolenic acids in MR during the first $60 \mathrm{~d}$ of life on growth, health, and immunity of Holstein calves.

\section{MATERIALS AND METHODS}

\section{Enrollment and Management of Pregnant Cows}

The experiment was approved by the University of Florida's Institutional Animal Care and Use Committee and conducted at the University of Florida's dairy farm. A weekly cohort of pregnant nulliparous $(\mathrm{n}=34)$ and previously parous $(\mathrm{n}=54)$ Holstein cattle were enrolled in the study starting 8 wk before calculated calving day.

Prepartum animals were housed in a common lot and fed once daily $(0800 \mathrm{~h})$ with a single TMR formulated to have low concentrations of total $(1.9 \%)$ and essential FA $(0.60 \%$ linoleic acid and $0.35 \% \alpha$-linolenic acid, DM basis, Table 1). Nonsilage feedstuffs in the TMR were combined to form a grain mix. Bermudagrass silage and corn silage samples were collected once a week and dried for $1 \mathrm{~h}$ using a Koster Moisture Tester (Koster Crop Tester Inc., Strongsville, OH) for DM determination. Proportions of silages and grain mix in the ration were adjusted weekly based on weekly DM values to maintain the formulated silage-to-concentrate ratio (55.3:44.7, DM basis). Offered feed was adjusted daily to achieve 5 to $10 \%$ orts. Orts were collected and weighed daily. Weekly samples of silage and grain mix were ground to pass through a 1-mm screen using a Wiley mill (Arthur H. Thomas Co., Philadelphia, PA). Samples were composited monthly, pooled in a single sample, and analyzed using wet chemistry procedures (Dairyland Laboratories Inc., Arcadia, WI; Table 1).

\section{Calving Management and Colostrum Feeding}

Calves were born between January 4 and April 5, 2011. Pregnant animals were monitored for signs of initiating parturition at least every $2 \mathrm{~h}$. Within $2 \mathrm{~h}$ of birth, calves were weighed and ear-tagged, and the umbilical cord was disinfected with $10 \%$ betadine solution (Purdue Frederick Co., Norwalk, CT). Calves were housed temporarily (2 to $14 \mathrm{~h}$ of age) in individual pens $(1 \mathrm{~m} \times 1 \mathrm{~m})$ equipped with a heat lamp before being moved to individual wire enclosures $(1 \mathrm{~m} \times 1.5 \mathrm{~m})$ bedded with sand.

Parturient cows were milked within $6 \mathrm{~h}$ of calving and colostrum was harvested. The concentration of total IgG in colostrum was measured initially using a colostrometer (Biogenics, Mapleton, OR), and only colostrum of good quality ( $>50 \mathrm{~g} / \mathrm{L}$ of IgG) was frozen at $-20^{\circ} \mathrm{C}$ in 4 -L amounts. Immediately after being weighed, calves were given $4 \mathrm{~L}$ of thawed and warmed colostrum from dams participating in this study using an esophageal feeding tube. 
Table 1. Ingredient and chemical composition of diet fed to nonlactating, pregnant Holstein animals

\begin{tabular}{lr}
\hline Item & \\
\hline Ingredient, \% of DM & \\
Bermuda silage & 46.5 \\
Corn silage & 8.8 \\
Citrus pulp & 31.7 \\
Soybean meal & 9.2 \\
Mineral mix & 3.8 \\
Nutrient composition, DM basis & \\
CP, \% & 13.80 \\
NEE, Mcal/kg & 1.46 \\
NDF, \% & 39.85 \\
FA, \% & 1.87 \\
C18:0, \% & 0.06 \\
C18:2n-6, \% & 0.60 \\
C18:3n-3, \% & 0.35 \\
Ash, \% & 8.12 \\
Ca, \% & 1.26 \\
P, \% & 0.34 \\
Mg, \% & 0.40 \\
K, \% & 1.52 \\
Na, \% $\%$ & 0.18 \\
DCAD, mEq/100 g & 0.87 \\
\hline
\end{tabular}

${ }^{1}$ Contained (DM basis) $34.5 \%$ corn meal, $5.0 \%$ dicalcium phosphate, $16.0 \%$ calcium carbonate, $10 \%$ calcium sulfate, $5 \%$ magnesium oxide, $10 \%$ magnesium sulfate, $4 \%$ sodium chloride, $1.7 \%$ Zinpro 4-plex (Zinpro, Minneapolis, MN), 0.4\% Rumensin 80 (Elanco Animal Health, Greenfield, IN), 0.35\% Sel-Plex 2000 (Alltech Biotechnology, Nicholasville, KY), $0.002 \%$ Ca iodate, and a vitamin premix. Each kilogram contained $24.5 \% \mathrm{CP}, 9.8 \% \mathrm{Ca}, 1.5 \% \mathrm{P}, 4.2 \% \mathrm{Mg}, 3.2 \% \mathrm{~S}, 1.7 \%$ $\mathrm{Na}, 10.7 \% \mathrm{Cl}, 475 \mathrm{mg}$ of $\mathrm{Zn}, 160 \mathrm{mg}$ of $\mathrm{Cu}, 456 \mathrm{mg}$ of $\mathrm{Mn}, 7.4 \mathrm{mg}$ of Se, $37.4 \mathrm{mg}$ of Co, $13.2 \mathrm{mg}$ of I, 118,000 IU of vitamin A, 27,500 IU of vitamin $\mathrm{D}, 2,600 \mathrm{IU}$ of vitamin $\mathrm{E}$, and $770 \mathrm{mg}$ of monensin.

${ }^{2}$ Calculated from the estimation of energetic values of individual ingredients using NRC (2001) and considering intake at $3 \times$ maintenance.

\section{Measure of Adequate Passive Immune Transfer}

Blood and colostrum sampling and measure of adequate passive transfer (APT) were performed according to Garcia et al. (2014a) with some modifications. Briefly, colostrum fed and serum samples of newborn calves were measured for concentrations of bovine total IgG using a single radial immunodiffusion method (Triple J Farms, Bellingham, WA). Colostrum and serum samples were diluted with sterile saline $(0.9 \% \mathrm{NaCl})$ at final concentrations of 15 and $70 \%$, respectively. Diluted samples $(5 \mu \mathrm{L})$ were applied to the wells of serial radial immunodiffusion plates containing agarose gel with anti-bovine IgG. Plates were left undisturbed for $27 \mathrm{~h}$ at room temperature. Resulting ring diameters were measured with a monocular comparator (VMRD Inc., Pullman, WA). A standard curve was plotted with reference sera $(1.96,14.02$, and $27.48 \mathrm{~g} / \mathrm{L}$ of $\operatorname{IgG}$ ) supplied by the manufacturer. Interassay $\mathrm{CV}$ was $3.6 \%$. Calves were considered to have APT if serum concentration of total $\operatorname{IgG}$ was $\geq 10 \mathrm{~g} / \mathrm{L} 24 \mathrm{~h}$ after feeding of colostrum (Tyler et al., 1996).

\section{Dietary Treatments, Feeding Management, Growth Measures, and Feed Analyses}

Calves were blocked by sex ( 54 females and 34 males) and by parity of the dam and assigned randomly to receive 1 of $4 \mathrm{MR}$ from 1 to $60 \mathrm{~d}$ of life. A low-fat, powdered MR was prepared commercially (9.5\% fat, DM basis; Land O'Lakes Animal Milk Products Co., Shoreview, MN) to serve as the base liquid feed. Milk replacers were prepared by partially replacing hydrogenated coconut oil (CCO; Welch, Holme and Clark Co. Inc., Newark, NJ) with increasing amounts of soybean oil (SBO; Winn Dixie Co., Jacksonville, FL) which was the source of linoleic and linolenic acids in 4 milk replacers. The treatment $(\mathbf{T})$ ratios of $\mathrm{CCO}$ and SBO were as follows: 100:0 (T1), 96.0:4.0 (T2), 87.9:12.1 (T3), and 71.8:28.2 (T4). Individual calves were offered amounts of MR to achieve intakes of 0.119 and 0.007 (T1), 0.187 and 0.017 (T2), 0.321 and 0.036 (T3), or 0.593 and $0.076(\mathrm{~T} 4) \mathrm{g} / \mathrm{kg}$ of metabolic BW $\left(\mathrm{BW}^{0.75}\right)$ of linoleic acid and $\alpha$-linolenic acid, respectively. These feeding rates for linoleic acid were selected to be below and above the recommended intake of linoleic acid by rats (NRC, 1995) and from results of our previous study with preweaned Holstein calves (Garcia et al., 2014b). The FA profiles of CCO, SBO, basal MR, and emulsifier are described in Table 2.

The amounts of SBO and $\mathrm{CCO}$ (stored at $\sim 4^{\circ} \mathrm{C}$ ) required at each feeding were heated to between 70 and $80^{\circ} \mathrm{C}$ using a microwave oven followed by the addition of an emulsifier (Grindsted Mono-Di HV $52 \mathrm{~K}-\mathrm{A}$, Danisco USA Inc., Madison, WI) added at $3 \%$ of the oils. Immediately, the blend of oils and emulsifier was transferred into insulated containers. Powdered MR and warm water $\left(40\right.$ to $43^{\circ} \mathrm{C}$ ) were mixed using an electric drill with a wire whisk attachment to prepare an $11 \%$ DM solution. The blend of oils and emulsifier was added to the MR base solution and whisked again. Oil droplets were not observed on the surface after mixing. The temperature of the liquid MR fed to the calves ranged between 35 and $38^{\circ} \mathrm{C}$. Each calf was monitored to ensure that the MR offered in plastic pails was consumed within 10 min of offer. Those rare calves not willing to drink within 10 min were fed using a nipple bottle (preferably) or an esophageal feeder. The temperature of MR was verified to be within the desired temperature range and the MR was warmed in a hot water bath if needed for these calves.

Milk replacer was fed at $33 \mathrm{~g}$ of DM per $\mathrm{kg}$ of $\mathrm{BW}^{0.75}$ divided in 2 daily feedings at 0600 and $1230 \mathrm{~h}$. This intake would support approximately $300 \mathrm{~g}$ of BW of ADG (NRC, 2001). Amounts of MR DM offered were increased weekly based upon BW measured at birth and once weekly throughout the 60-d study. However, 
Table 2. Fatty acid profile of sources of oil, emulsifier, basal milk replacer, and concentrate

\begin{tabular}{lccccc}
\hline FA & $\begin{array}{c}\text { Coconut } \\
\text { oil }^{1}\end{array}$ & $\begin{array}{c}\text { Soybean } \\
\text { oil }^{2}\end{array}$ & Emulsifier $^{3}$ & $\begin{array}{c}\text { Milk } \\
\text { replacer }^{4}\end{array}$ & Concentrate $^{{ }^{2}}$ \\
\hline C6:0 & 0.6 & ND $^{5}$ & ND & 0 & ND \\
C8:0 & 7.8 & ND & ND & 4.1 & 2.0 \\
C10:0 & 6.2 & ND & ND & 3.1 & 0.0 \\
C12:0 & 50.0 & ND & ND & 29.4 & 0.0 \\
C14:0 & 18.1 & 0.1 & 0.1 & 14.4 & 0.3 \\
C16:0 & 8.4 & 11.4 & 11.1 & 17.7 & 0.2 \\
C16:1 & ND & 0.1 & ND & 0.6 & 1.8 \\
C18:0 & 8.7 & 4.0 & 87.9 & 7.0 & 13.3 \\
C18:1 & 0.1 & 20.5 & 0.1 & 15.8 & 5.8 \\
C18:2n-6 & 0.0 & 55.3 & 0.1 & 0.3 & 4.7 \\
C18:3n-3 & 0.0 & 8.1 & 0.0 & 0.3 & 0.2 \\
C20:0 & 0.1 & 0.3 & 0.5 & 2.2 & 1.8 \\
Other & 0.0 & 0.2 & 0.2 & & \\
\hline
\end{tabular}

${ }^{1}$ Welch, Holme and Clark Co. Inc. (Newark, NJ).

${ }^{2}$ Winn Dixie Co. (Jacksonville, FL).

${ }^{3}$ Grindsted Mono-Di HV 52 K-A (Danisco USA Inc., Madison, WI).

${ }^{4}$ Prepared by Land O'Lakes (Shoreview, MN).

${ }^{5}$ Not detected.

calves that lost BW in a 7 -d period were offered the same amount of MR as that offered in the previous week. The afternoon MR feeding was replaced with electrolytes if diarrheic calves were not willing to drink voluntarily. Body weight and wither and hip heights were recorded as measures of growth at 0,30 , and $60 \mathrm{~d}$ of age. Body weight at $0 \mathrm{~d}$ of age was measured before feeding of colostrum, and height was measured within $12 \mathrm{~h}$ of birth, whereas BW and height at 30 and $60 \mathrm{~d}$ of age were measured before the morning feeding of MR. Calves were fed MR exclusively during the first $30 \mathrm{~d}$ of life. A single concentrate mix of a low concentration of linoleic acid was offered in ad libitum amounts starting at $31 \mathrm{~d}$ of age (Table 3). Clean water was available in ad libitum amounts at all times. Powdered MR and grain mix were sampled weekly, composited monthly, and then composited in a single sample for chemical analyses (Dairyland Laboratories Inc., Arcadia, WI).

\section{Calf Scoring for Health Assessment and Incidence of Health Disorders}

Attitude, fecal consistency, and nasal discharge were scored daily after the first daily feeding of MR by a single observer using a scale from 0 to 3 (http://www. vetmed.wisc.edu/dms/fapm/fapmtools/8calf/calf_ health_scoring_chart.pdf). Calves given a fecal score $>1$ were considered to have diarrhea and those with a score of 3 were considered to have severe diarrhea. Calves given a score $>0$ for other criteria were considered as having the disorder. Weekly averages of all scores were generated per calf for statistical analysis.
Incidences of health disorders were recorded daily for individual calves. Rectal temperature was measured daily during the first $14 \mathrm{~d}$ of age, as well as on days when the calf displayed clinical signs of disease such as diarrhea, bloat, coughing, increased respiratory frequency, depression, or lack of appetite. Calves with a rectal temperature $\geq 39.5^{\circ} \mathrm{C}$ were categorized as febrile. Duration in days and number of episodes of each illness event was recorded. To distinguish between different episodes, intervals of 4,4 , and $10 \mathrm{~d}$ between diagnoses of fever, diarrhea, and pneumonia, respectively, had to elapse to establish a new disease event. A calf was considered pneumonic if it had fever with at least one clinical sign of respiratory disease (mucopurulent nasal discharge, cough, increased respiratory rate, increased respiratory effort, or abnormal lung sounds auscultated by the herd veterinarian). Calves without fever but being depressed and showing at least 2 clinical signs of respiratory disease also were considered pneumonic. A navel was considered infected if it was enlarged, firm, and painful on palpation, regardless of purulent discharge. Calves were vaccinated according to the herd vaccination protocol. Calves with digestive and respiratory problems were treated by farm personnel according to protocols established by the herd veterinarian. Use of antiinflammatory drugs were avoided, except for 4 calves that were treated once. Three calves were treated with flunixin meglumine (Banamine; Merck Animal Health, Summit, NJ) at 2 (T1), 57 (T1), or 59 (T4) d of age, and 1 calf (T4) was treated with dexamethasone (Zoetis, Madison, NJ) at d 2 of age. Calves given these antiinflammatory drugs were not evaluated for measures of immune responses during the periods of drug clearance. 


\section{Hormone and Metabolite Analyses}

Calves were bled $(16 \mathrm{~mL})$ at 24 to $30 \mathrm{~h}$ after colostrum feeding and at 8, 15, 22, 29, 36, 43, 50, and $57 \pm 1$ $\mathrm{d}$ of age from the jugular vein. Blood was collected into tubes without anticoagulant and with $\mathrm{K}_{2}$ EDTA and then centrifuged at $4^{\circ} \mathrm{C}$ for $15 \mathrm{~min}$ at 2,095 $\times g$ for harvesting of serum and plasma, respectively. Hematocrit concentration was determined in blood collected into $\mathrm{K}_{2}$ EDTA tubes using micro-hematocrit capillary tubes (Fisherbrand, Thermo Fisher Scientific Inc., Waltham, MA), centrifuged for $3 \mathrm{~min}$ (Microspin 24 tube micro hematocrit centrifuge; Vulcon Technologies, Grandview, MO) and read in a micro hematocrit tube reader (model CR; Damon/IEC, Needham Heights, MA). Before freezing, serum total protein (STP) was measured using an automatic temperature-compensated refractometer (Reichert Jung; Cambridge Instruments Inc., Buffalo, NY).

Concentrations of glucose, plasma urea N (PUN), BHBA, and cholesterol were determined in all 9 plasma samples. A Technicon Autoanalyzer (Technicon Instruments Corp., Chauncey, NY) was used to measure concentrations of plasma glucose (Bran and Luebbe Industrial Method 339-19; Gochman and Schmitz, 1972) and PUN (Bran and Luebbe Industrial Method 33901; Marsh et al., 1965). Each run included a common control sample. Intra- and interassay CV, respectively, were 1.0 and $1.3 \%$ for glucose and 3.0 and $4.2 \%$ for PUN. Plasma concentrations of BHBA were determined using a commercial kit (Autokit 3-HB; Wako Diagnostics Inc., Richmond, VA). Intra- and interassay $\mathrm{CV}$ were 5.6 and $7.8 \%$, respectively. Concentrations of total cholesterol in plasma were determined using a commercial kit (Cholesterol E kit; Wako Diagnostics Inc., Richmond, VA). Intra- and interassay $\mathrm{CV}$ were 3.2 and $6.8 \%$, respectively.

Insulin and IGF-I were measured in serum taken before feeding of colostrum and in plasma samples taken at 24 to $30 \mathrm{~h}$ after colostrum feeding and at 15, 29, 43, and $57 \pm 1 \mathrm{~d}$ of age. Concentrations of IGF-I were analyzed following the manufacturer's protocol (Quantine ELISA; Human IGF-I Immunoassay, R\&D Systems Inc., Minneapolis, MN) The intra- and interassay CV were 3.6 and $8.1 \%$, respectively. Concentrations of insulin were analyzed by a double-antibody RIA (Badinga et al., 1991). Intra- and interassay CV were 7.3 and $14.6 \%$, respectively.

A liver sample was collected via intercostal needle biopsy at $30 \mathrm{~d}$ of age, frozen in liquid $\mathrm{N}_{2}$, and freezedried. A freeze-dried liver sample $(\sim 0.50 \mathrm{~g})$ was placed into a screw-cap tube and $1 \mathrm{~mL}$ of C19:0 (internal standard), $0.7 \mathrm{~mL}$ of $10 \mathrm{~N} \mathrm{KOH}$, and $5.3 \mathrm{~mL}$ of $\mathrm{MeOH}$ were added to produce methyl esters of FA (O'Fallon et
Table 3. Ingredient and chemical composition of milk replacer and concentrate fed to preweaned Holstein calves

\begin{tabular}{|c|c|c|}
\hline Item & $\begin{array}{c}\text { Milk } \\
\text { replacer }\end{array}$ & Concentrate \\
\hline \multicolumn{3}{|l|}{ Ingredient, $\%$ of DM } \\
\hline $31: 7$ milk replacer $^{1}$ & 89.80 & - \\
\hline Oil combination $^{2}$ & 9.68 & - \\
\hline Emulsifier $^{3}$ & 0.48 & - \\
\hline Steam rolled barley & - & 51.7 \\
\hline Soybean meal & - & 16.5 \\
\hline Beet pulp shreds & - & 24.5 \\
\hline Sugarcane molasses & - & 5.3 \\
\hline Mineral mix ${ }^{4}$ & - & 2.0 \\
\hline \multicolumn{3}{|c|}{ Nutrient composition, DM basis } \\
\hline Lactose, $\%$ & 39.70 & - \\
\hline $\mathrm{CP}, \%$ & 29.70 & 18.30 \\
\hline FA, \% & 15.52 & 1.86 \\
\hline Ash, $\%$ & 6.08 & 5.42 \\
\hline $\mathrm{Ca}, \%$ & 0.77 & 0.57 \\
\hline $\mathrm{P}, \%$ & 0.72 & 0.45 \\
\hline $\mathrm{Mg}, \%$ & 0.13 & 0.35 \\
\hline $\mathrm{K}, \%$ & 2.12 & 0.92 \\
\hline $\mathrm{S}, \%$ & 0.39 & 0.26 \\
\hline $\mathrm{Na}, \%$ & 0.76 & 0.16 \\
\hline $\mathrm{Cl}, \%$ & 1.27 & 0.32 \\
\hline $\mathrm{Mn}, \mathrm{mg} / \mathrm{kg}$ & 49.5 & 55.0 \\
\hline $\mathrm{Zn}, \mathrm{mg} / \mathrm{kg}$ & 53.0 & 57.0 \\
\hline $\mathrm{Cu}, \mathrm{mg} / \mathrm{kg}$ & 11.7 & 16.0 \\
\hline $\mathrm{Fe}, \mathrm{mg} / \mathrm{kg}$ & 132.0 & 362.0 \\
\hline $\mathrm{Mo}, \mathrm{mg} / \mathrm{kg}$ & 0.6 & 1.4 \\
\hline
\end{tabular}

${ }^{1}$ Prepared by Land O'Lakes (Shoreview, MN). Contained whey products, dried skim milk, dried milk protein, coconut oil, vitamins, and minerals. Each kilogram contained $1.03 \% \mathrm{Ca}, 0.80 \% \mathrm{P}, 0.11 \mathrm{mg}$ of Co, $10.9 \mathrm{mg}$ of $\mathrm{Cu}, 1.1 \mathrm{mg}$ of I, $110 \mathrm{mg}$ of $\mathrm{Fe}, 49,560 \mathrm{IU}$ of vitamin A, $12,400 \mathrm{IU}$ of vitamin D, and $241 \mathrm{IU}$ of vitamin $\mathrm{E}$.

${ }^{2}$ Contained proportions of coconut oil:soybean oil according to following treatments $(\mathrm{T}): \mathrm{T} 1=100: 0, \mathrm{~T} 2=96.0: 4.0, \mathrm{~T} 3=87.9: 12.1$, and $\mathrm{T} 4=71.8: 28.2$.

${ }^{3}$ Grindsted Mono-Di HV 52 K-A (Danisco USA Inc., Madison, WI).

${ }^{4}$ Each kilogram of DM contained $8.8 \%$ Ca, $4.2 \%$ P, $11.4 \% \mathrm{Mg}, 12.4 \%$ $\mathrm{Cl}, 0.49 \% \mathrm{~K}, 8.1 \% \mathrm{Na}, 0.36 \% \mathrm{~S}, 58 \mathrm{mg}$ of $\mathrm{Co}, 263 \mathrm{mg}$ of $\mathrm{Cu}, 26 \mathrm{mg}$ of I, $1,933 \mathrm{mg}$ of Fe, $923 \mathrm{mg}$ of Mn, $8.46 \mathrm{mg}$ of Se, 1,109 mg of Zn, 259,000 IU of vitamin A, 70,000 IU of vitamin D, and 2,400 IU of vitamin E.

al., 2007). Tubes were incubated for $1.5 \mathrm{~h}$ at $55^{\circ} \mathrm{C}$ with vigorous shaking for $5 \mathrm{~s}$ every $20 \mathrm{~min}$. After cooling to below room temperature, $0.58 \mathrm{~mL}$ of $24 \mathrm{~N} \mathrm{H}_{2} \mathrm{SO}_{4}$ was added. Again, tubes were incubated for $1.5 \mathrm{~h}$ at $55^{\circ} \mathrm{C}$ with vigorous shaking for $5 \mathrm{~s}$ every $20 \mathrm{~min}$. After cooling, $3 \mathrm{~mL}$ of hexane was added and vigorously vortexed, and the layer of hexane was placed into GLC vials. The FA were determined using a GLC (HewlettPackard 5890A) fitted with a $100 \mathrm{~m} \times 0.25 \mathrm{~mm} \times 0.20$ $\mu \mathrm{m}$ SP-256 capillary column as described by O'Fallon et al. (2007).

\section{Markers of Immunity Analyses}

Concentrations of haptoglobin $(\mathbf{H p})$ and acid-soluble protein (ASP) were measured in all 9 plasma samples collected as previously described. Haptoglobin was determined by measuring the differences of $\mathrm{H}_{2} \mathrm{O}_{2}$ with 
Hp-hemoglobin as described previously (Makimura and Suzuki, 1982). Concentrations of $\mathrm{Hp}$ are reported as arbitrary units [optical density $($ OD $) \times 100$ ] resulting from the absorption reading at $450 \mathrm{~nm}$. Intra- and interassay CV were 6.0 and $10.9 \%$, respectively. Concentrations of ASP were determined by extraction with $0.6 M$ perchloric acid using the bicinchoninic acid kit for protein determination (Sigma-Aldrich, St. Louis, $\mathrm{MO}$ ). The intra- and interassay CV were 2.6 and $5.9 \%$, respectively.

Blood was collected from puncture of the jugular vein into tubes containing heparin at 7, 14, 28, and $42 \pm 2$ $\mathrm{d}$ of age at least $30 \mathrm{~min}$ but not more than $2 \mathrm{~h}$ after the first daily feeding of MR. Tubes were transported to the laboratory at environmental temperature maintaining constant gentle inversion and analyzed within $2 \mathrm{~h}$ of collection. Quantification of individual cells and cell populations were performed using a ProCyte Dx hematology analyzer (Idexx Laboratories Inc., Westbrook, ME). Phagocytosis and oxidative burst of blood neutrophils were measured using a dual-color flow cytometry assay with the method modified from Smits et al. (1997) and according to the details provided by Martinez et al. (2012).

Proliferation of lymphocytes in whole blood cells was induced by a 72-h incubation without (control) or with concanavalin A (ConA, Sigma-Aldrich). Control and ConA samples were run in triplicate in 96-well flatbottomed sterile plates (Sigma-Aldrich). Briefly, blood samples from experimental calves at 14, 28, and $42 \pm$ $2 \mathrm{~d}$ of age were diluted 1:32 with RPMI-1640 medium without phenol red (Invitrogen, Life Technologies, Grand Island, NY) containing 1\% antibiotics (Gibco Antibiotic-Antimycotic, Invitrogen) and containing or not $5 \mu \mathrm{g} / \mathrm{mL}$ of ConA. Plates were incubated at $37^{\circ} \mathrm{C}$ with $5 \% \mathrm{CO}_{2}$. After $48 \mathrm{~h}$ of incubation, cells in each well were pulsed with $0.2 \mu \mathrm{Ci}$ of ${ }^{3}[\mathrm{H}]$-thymidine (MP Biomedicals, Irvine, CA). Incorporation of $\left[{ }^{3} \mathrm{H}\right]$-thymidine into DNA was assessed by liquid scintillation counting in a Beckman LS6000 counter (Pegasus Scientific Inc., Rockville, MD). Stimulation index was calculated as the ratio of the average value of counts per minute of the ConA wells to the average count per minute value of the control wells.

Production of cytokines by whole blood cells was induced by stimulation with $0.2 \mu \mathrm{g} / \mathrm{mL}$ of phytohemagglutinin (PHA, L1668; Sigma-Aldrich Co.) and $1 \mu \mathrm{g} /$ $\mathrm{mL}$ of LPS (Escherichia coli 0111:B4; Sigma-Aldrich Co.). This dose was selected from the 3 following doses of PHA + LPS tested $(0.2+1,1+5$, and 5 $+25 \mu \mathrm{g} / \mathrm{mL}$ ) based upon maximal concentrations of tumor necrosis factor (TNF)- $\alpha$ and IFN- $\gamma$ produced upon stimulation. Stimulation of whole blood cells was performed following the protocol of Hulbert et al. (2011) with some modifications. Briefly, blood samples of experimental calves at 14, 28, and $42 \pm 2 \mathrm{~d}$ of age were diluted 1:5 with RPMI-1640 medium without phenol red (Invitrogen) containing 1\% antibiotics (Gibco Antibiotic-Antimycotic, Invitrogen) and containing or not the $1 \mu \mathrm{g} / \mathrm{mL}$ of LPS and $0.2 \mu \mathrm{g} / \mathrm{mL}$ of PHA. Stimulated (PHA + LPS) and nonstimulated samples were incubated in triplicate in sterile 24 -well cell culture plates (Sigma-Aldrich Co.) for $48 \mathrm{~h}$ at $37^{\circ} \mathrm{C}$ and $5 \% \mathrm{CO}_{2}$. After incubation, plates were centrifuged for 12 min at 1,455 $\times g$ (Allegra X-15R centrifuge, Beckman Coulter Inc., Brea, CA). The supernatant was pooled and stored at $-80^{\circ} \mathrm{C}$ until analyzed for bovine TNF- $\alpha$ and IFN- $\gamma$. Quantification of TNF- $\alpha$ and IFN- $\gamma$ was performed only on stimulated supernatant samples because preliminary results from the validation test indicated that the concentrations of cytokines of nonstimulated cells were low $(<12 \mathrm{pg} / \mathrm{mL})$. Bovine TNF- $\alpha$ and IFN- $\gamma$ assays (Vet Sets ELISA Development Kit; Kingfisher Biotech Inc., St. Paul, MN) were used according to manufacturer's procedures. Stimulated samples were analyzed in duplicate including a control. Standards were prepared with RPMI-1640 medium including $1 \%$ antibiotics; stimulated samples were not diluted. The intra- and interassay CV, respectively, were 2.0 and $11.4 \%$ for TNF- $\alpha$, and 8.4 and $13.2 \%$ for IFN- $\gamma$. The sensitivity of the assay was 78 and $125 \mathrm{pg} /$ $\mathrm{mL}$ for TNF- $\alpha$ and IFN- $\gamma$, respectively.

Cell-mediated hypersensitivity to epidermal injection of PHA (L1668; Sigma-Aldrich Co.) was performed in calves at $29 \pm 1$ and 58 or 59 d of age. The treated shoulder was shaved and cleaned with $78 \%$ alcohol. The area to be injected was identified by drawing a circle. The epidermal injection of PHA (200 $\mu \mathrm{g}$ dissolved in $100 \mu \mathrm{L}$ of sterile isotonic saline solution) was made in the middle of the drawn circle using insulin syringes. Skin-fold thickness was measured at $0,6,24$, and $48 \mathrm{~h}$ after injection using a digital caliper (Mitutoyo, Kawasaki, Kanagawa, Japan). The proportional increase in diameter of the skin-fold thickness was recorded to determine delayed-type hypersensitivity (DTH) response to PHA injection.

Concentrations of bovine IgG against ovalbumin (OVA) were measured in serum of calves injected s.c. with $0.5 \mathrm{mg}$ of OVA (Sigma Aldrich) diluted in Quil A adjuvant (Accurate Chemical, Westbury, NY) solution (0.5 mg of Quil A in $1 \mathrm{~mL}$ of PBS) using sterile procedures at 1, 22, and $43 \mathrm{~d}$ of age. Bovine anti-OVA IgG were measured on the same days of injection and at $57 \mathrm{~d}$ of age by the method described by Mallard et al. (1997). Intra- and interassay CV were 3.6 and 3.8\%, respectively. 


\section{Statistical Analyses}

The experiment was a completely randomized design. Newborn calves were blocked by sex and parity of the dam and assigned randomly to receive 1 of $4 \mathrm{MR}$ treatments on the day of birth. Nearly all dependent variables were measured repeatedly and analyzed using the PROC GLIMMIX procedure of SAS (release 9.2; SAS Institute Inc., Cary, NC) using the following model:

$$
\begin{gathered}
\mathrm{Y}_{\mathrm{ijkl}}=\mu+\mathrm{T}_{\mathrm{i}}+\mathrm{G}_{\mathrm{j}}+(\mathrm{TG})_{\mathrm{ij}}+\mathrm{C}\left(\left(_{\mathrm{ij}}\right)_{\mathrm{k}}+\mathrm{A}_{\mathrm{l}}\right. \\
+(\mathrm{TA})_{\mathrm{il}}+(\mathrm{GA})_{\mathrm{jl}}+(\mathrm{TGA})_{\mathrm{ijl}}+\varepsilon_{\mathrm{ijk} \mathrm{k}}
\end{gathered}
$$

where $Y_{i j k l}$ is the observation, $\mu$ is overall mean, $T_{i}$ is the fixed effect of MR i (T1, T2, T3, and T4), $\mathrm{G}_{\mathrm{j}}$ is the fixed effect of sex $\mathrm{j}$ (male and female), (TG) $)_{\mathrm{ij}}$ is the interaction of $\mathrm{MR}$ with sex, $\mathrm{C}(\mathrm{ij})_{\mathrm{k}}$ is the random effect of calf $\mathrm{k}$ nested within $\mathrm{MR}$ and sex $(1,2,3, \ldots, \mathrm{n}), \mathrm{A}_{1}$ is the fixed effect of age 1 in weeks or days $(0,1,2, \ldots, n)$, $(\mathrm{TA})_{\mathrm{il}}$ is the interaction of MR with age, $(\mathrm{GA})_{\mathrm{j} 1}$ is the interaction of sex with age, (TGA) $)_{\mathrm{ijl}}$ is the interaction of MR with sex with age, and $\varepsilon_{\mathrm{ijkl}}$ is the residual error. For nonrepeated measures, the same model was used after removing the age effect and their interactions.

Data were tested for normality of residuals using the Shapiro-Wilk test of SAS (version 9.2; SAS Inst. Inc.), and transformation was performed to achieve normality as needed. Repeated measures were tested to determine the structure of best fit as indicated by the smallest Schwartz Bayesian information criteria. If repeated measures were taken on unequally spaced intervals, the spatial power $[\mathrm{sp}(\mathrm{pow})]$ structure was used.

Coefficients for testing of orthogonal contrasts when using unequally spaced quantitative treatments were generated using PROC IML of SAS (SAS Inst. Inc). Orthogonal contrasts performed were as follows: (1) linear effect of treatment, (2) quadratic effect of treatment, (3) cubic effect of treatment, (4) sex effect, (5) interaction of contrasts 1 and 4, (6) interaction of contrasts 2 and 4, and (7) interaction of contrasts 3 and 4. If a 3-way interaction of age with the main effects of treatment and sex or interaction of age with sex had $P$ $>0.25$, the interactions were dropped from the model.

Binary data were analyzed by logistic regression using the LOGISTIC procedure of SAS (SAS Inst. Inc.). The models included the effects of treatment and sex of calf. Adjusted odds ratio and 95\% CI were calculated. Birth weight and height deviations within each sex were covariates for analysis of BW gain and growth, respectively. First-day measures of plasma metabolites and anti-OVA IgG were used as a covariate for the same compounds. Finally, serum total IgG concentration at $1 \mathrm{~d}$ of life was used as a covariate for health measures.
Differences discussed in the text were significant at $P$ $\leq 0.05$ and tended to be significant at $0.05<P \leq 0.10$.

\section{RESULTS AND DISCUSSION}

\section{Adequate Passive Immunity}

At 24 to $30 \mathrm{~h}$ after consumption of colostrum, mean concentrations of total IgG in serum and of STP were $21.5,21.4,19.8$, and $22.9 \mathrm{~g} / \mathrm{L}(\mathrm{SEM}=1.5 \mathrm{~g} / \mathrm{L})$ and $5.8,5.9,5.8$, and $5.8 \mathrm{~g} / \mathrm{dL}(\mathrm{SEM}=0.1 \mathrm{~g} / \mathrm{dL})$ for $\mathrm{T} 1$, $\mathrm{T} 2$, T3, and T4, respectively. Both IgG and STP values were above the minimum concentrations recommended to ensure APT (Tyler et al., 1996). Two calves assigned to $\mathrm{T} 2$ and 1 calf assigned to T3 failed to attain APT after colostrum feeding (serum total IgG $<10 \mathrm{~g} / \mathrm{L}$ ), which was corroborated by their low concentration of STP $(<5 \mathrm{~g} / \mathrm{dL})$ measured at 24 to $30 \mathrm{~h}$ after colostrum feeding; however, performance of these calves was not different from that of their treatment mates. Mean concentrations of STP exceeded $5.5 \mathrm{~g} / \mathrm{dL}$ throughout the duration of the study and were not affected by increased intake of essential FA (data not shown).

\section{Liver FA Concentration and Profile}

Concentrations of total FA in liver of $30 \mathrm{~d}$-old calves did not differ because of treatment and averaged 8.4 $\pm 0.5 \mathrm{~g} / 100 \mathrm{~g}$ of DM. Contrary to the current finding, Jenkins and Kramer (1986) reported reductions of approximately 30 and $20 \%$ in proportions of $\mathrm{FA}$ in fresh liver of calves fed CCO-based MR compared with MR that replaced 5 or $7.5 \%$ of $\mathrm{CCO}$ with corn or canola oil, respectively $(10.7,7.2$, and $8.2 \%$ of total liver DM, respectively, assuming liver tissue was $20 \%$ DM) . However, those authors reported that calves fed CCO-MR had a better growth performance, which might indicate that liver function was not impaired by this increase in fat concentration.

Concentrations of C12:0 $(P=0.01)$ and $\mathrm{C} 14: 0(P=$ 0.01 ) decreased linearly with increasing replacement of CCO with SBO in the MR (Figure 1A), as expected, based upon the medium-chain FA profile of the $2 \mathrm{FA}$ sources (Table 2). Concentrations of the longer chain SFA were decreased moderately $(\mathrm{C} 16: 0, P=0.03)$ or unchanged (C18:0, Figure 1B) by feeding more SBO because the 2 oil sources differed little in their concentrations of $\mathrm{C} 16: 0$ and $\mathrm{C} 18: 0$ (Table 2). The magnitude of linear increase $(P<0.01)$ in the essential FA concentrations with increasing intake of SBO was dramatic, being 63 and $145 \%$ for linoleic acid and $\alpha$-linolenic acid, respectively (Figures $1 \mathrm{C}$ and D) and reflected dietary profiles of these 2 FA. Jenkins and Kramer (1986) also reported greater proportions of linoleic acid in calf liver 
by replacing some or all of the $\mathrm{CCO}$ with a source of fat containing linoleic acid. Calves fed increasing amounts of SBO compared with CCO consumed more C18:1 cis9 but liver concentrations of C18:1 cis- 9 decreased with increasing intake of the 2 essential FA (Figure 1B). The decrease of C18:1 cis-9 likely reflected a substitution by the essential FA for C18:1 cis-9 in the triglyceride and phospholipid fractions of liver. This accompaniment of increasing linoleic acid and decreasing C18:1 cis-9 concentrations agrees with the FA patterns of the liver of male (Mohrhauer and Holman, 1963) and female growing rats (Pudelkewicz et al., 1968) fed increasing amounts of ethyl linoleate in otherwise fat-free diets. The concentration of $\mathrm{C} 20: 4 \mathrm{n}-6$ (the main derivative of linoleic acid) was consistent and not affected by feeding more linoleic acid, averaging $11.4 \%$ of liver FA content (Figure 1C). Similarly, the concentration of $\mathrm{C} 20: 4 n-6$ did not change in liver of growing female rats fed increasing amounts of ethyl linoleate once the requirement for linoleic acid was thought to be met (Pudelkewicz et al., 1968). Concentration of C22:5n-3 appeared to increase linearly at the same rate as that of $\alpha$-linolenic acid (Figure 1D), whereas other n-3 derivatives (C20:5 and C22:6) decreased or tended to decrease in liver of calves fed increasing amounts of $\alpha$-linolenic acid (Figure 1E), suggesting a teleologic demand for C22:5n-3. Most of the studies addressing the essentiality of $\alpha$-linolenic acid have focused on the role of its derivative, DHA, in brain development (Innis, 2007). A recent review by Kaur et al. (2011), primarily based on in vitro and in vivo studies in rodents, suggests unique and shared functions of docosapentaenoic acid (DPA) with DHA, such as enhanced endothelial migration, synthesis of DPA-related eicosanoids, and regulation of gene expression. In the current study, the FA profile of immune cells was not determined; however, several studies using rodents reported that the phospholipid fraction of immune cells was enriched in long-chain dietary FA (Calder, 2008). The phospholipid fraction normally accumulates more of the long-chain FA than does the triglyceride fraction. The FA profile of the phospholipid fractions in the liver were not measured in the current study. However, based on previous studies, the phospholipid fraction of liver as well as that of immune cells may have been enriched in essential FA derivatives.

Mead and Slaton (1956) reported that C20:3n-9, subsequently called mead acid, accumulated in organs and depot fat of male rats fed a fat-deficient diet. In the current study, in which diets were isolipidic, the mean concentration of C20:3n-9 in liver decreased linearly and dramatically $(P<0.01)$ with increasing intake of linoleic acid (Figure $1 \mathrm{~F}$ ). However, the ratio of $\mathrm{C} 20: 3 \mathrm{n}-9$ to $\mathrm{C} 20: 4 \mathrm{n}-6$ was $<0.2$, which others have used as a metabolic indicator of linoleic acid sufficiency in nonruminant animals (Holman, 1978). Lambs and calves have very low concentrations of linoleic acid at birth, but concentrations increase 12- to 14 -fold by 30 d of age (Noble et al., 1975; Garcia et al., 2014a,b). Presumably, preruminant calves have developed a mechanism to optimize the efficiency of linoleic acid utilization under the conditions of a low supply by the dam, as also pointed out for the young lamb by Noble et al. (1972).

\section{Measures of Growth and Feed Efficiency}

Birth weight of calves did not differ across treatments and averaged $39.9 \mathrm{~kg}$ (Table 4), with males being heavier than females (42.0 vs. $37.7 \mathrm{~kg} ; P<0.01$ ). Gain in BW during the first $30 \mathrm{~d}$ of life was below industry standards, with ADG of $111 \mathrm{~g}$. Ballou and DePeters (2008) also reported ADG of $<100 \mathrm{~g}$ when averaged over the first 4 wk of life for Jersey bull calves fed only MR formulated and fed for $300 \mathrm{~g}$ of ADG. Male calves assigned to T2 tended $(P=0.09)$ to consume more MR DM compared with males fed other MR treatments due to less refusal of MR, whereas female calves consumed similar amounts of MR across treatments (sex by cubic treatment interaction, Table 4$)$. Body weight gain $(P=$ 0.02 ) and feed efficiency (FE, $P=0.04$ ), measured as kilograms of BW gain per kilogram of DMI, by male calves followed the same cubic pattern of MR intake (sex by cubic treatment interaction). This positive response of male calves fed T2 was not replicated in the second $30 \mathrm{~d}$ of life nor did it carry over for the entire 60-d study (Table 4). A slightly greater intake of MR by male calves fed T2 (17 to $20 \mathrm{~g} / \mathrm{d}$ increase) compared with other male calves would not account nutritionally for the almost doubling of BW gain for this treatment group, suggesting that improved growth of $\mathrm{T} 2$-fed calves may have been due partly to meeting a metabolic demand for linoleic acid and (or) $\alpha$-linolenic acid. However, an improved BW gain was not maintained by male calves fed T3 or T4 diets. Based upon dermal scores, concentration of C20:4n-6 in erythrocytes, BW gain, and FE, Pudelkewicz et al. (1968) reported that the optimum intake of linoleic acid for growing rats was narrow and that consumption of linoleic acid exceeding this optimum range resulted in reduced performance.

Total BW gain by female calves during the first 30 d tended $(P=0.07)$ to increase linearly with increasing intake of essential FA $(2.6,3.1,3.3$, and $3.4 \mathrm{~kg}$ for T1, T2, T3, and T4, respectively, Table 4). Feed efficiency of female calves followed a similar numeric increase (sex by linear diet interaction, $P=0.11$ ). In a previous study from our laboratory, unweaned Holstein calves, regardless of sex, had lower ADG and FE when 
A)

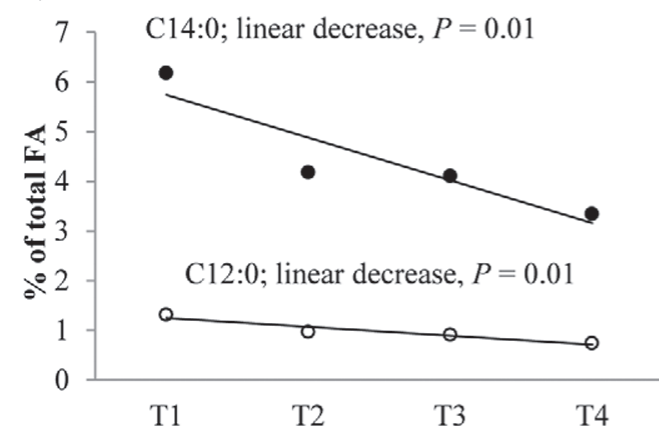

C)

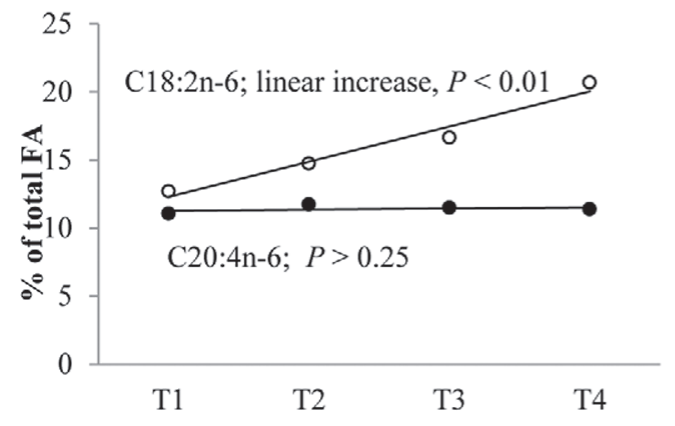

E)

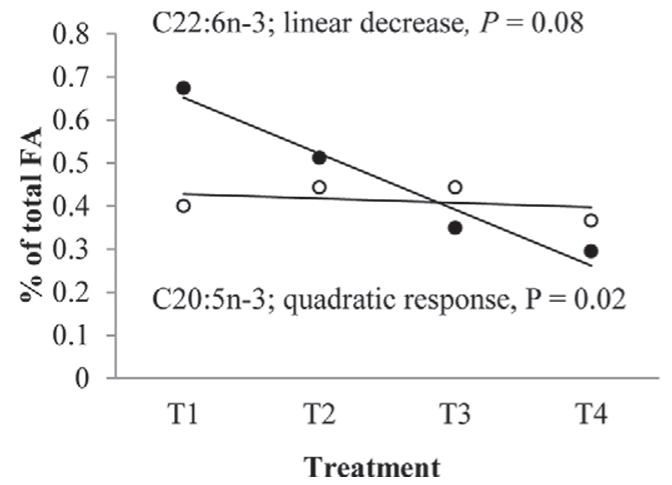

B)

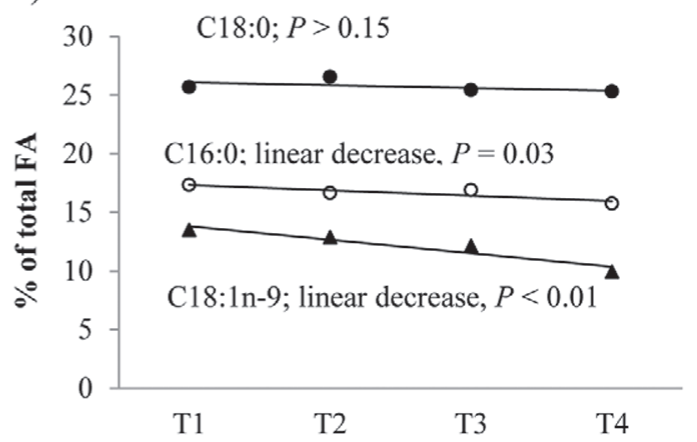

D)

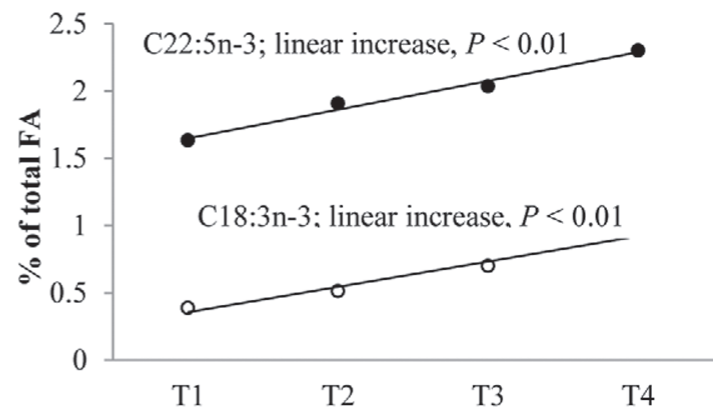

F)

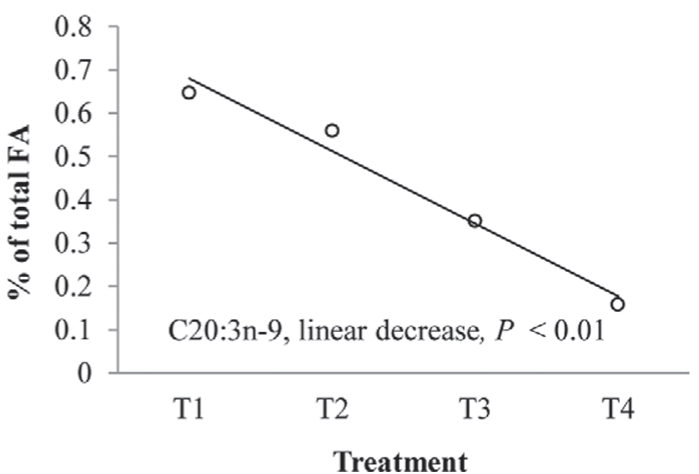

Figure 1. Concentration of selected FA in liver of 30-d-old preweaned Holstein calves fed linoleic and $\alpha$-linolenic acids at 0.119 and 0.007 (T1), 0.187 and 0.017 (T2), 0.321 and 0.036 (T3), and 0.593 and 0.076 (t4) $\mathrm{g} / \mathrm{kg}$ of BW ${ }^{0.75}$ in milk replacer.

fed reduced amounts of linoleic acid $(0.14 \mathrm{~g}$ per $\mathrm{kg}$ of $\mathrm{BW}^{0.75}$ ) compared with calves fed essential FA at 0.45 and $0.04 \mathrm{~g}$ of linoleic and $\alpha$-linolenic acids per $\mathrm{kg}$ of $\mathrm{BW}^{0.75}$, respectively (Garcia et al., 2014b). Jenkins and Kramer (1986) fed only MR formulated with hydrogenated CCO, hydrogenated CCO plus corn oil, hydrogenated CCO plus canola oil, or tallow to preweaned dairy calves for $6 \mathrm{wk}$. In that study, calculated mean intakes of linoleic and $\alpha$-linolenic acids were 0.2 and 0 , 5.0 and $0.0,2.7$ and 1.7 , and 9.3 and $1.1 \mathrm{~g} / \mathrm{d} ; \mathrm{ADG}$ was $600,640,671$, and $731 \mathrm{~g} / \mathrm{d}$; and DMI was 935, 973, 990, and $1,018 \mathrm{~g} / \mathrm{d}$ for calves fed the $4 \mathrm{MR}$, respectively.
Although performance appeared to be greater if some linoleic acid was fed, only tallow-fed calves had better ADG compared with those fed CCO alone.

Wither and hip heights of calves at birth were not different across treatments and averaged $75.3 \pm 0.70$ and $79.8 \pm 0.73 \mathrm{~cm}$, respectively. Over the 60 -d study, growth at the withers $(7.6,8.6,9.1$, and $8.3 \pm 0.47 \mathrm{~cm}$ for $\mathrm{T} 1, \mathrm{~T} 2$, $\mathrm{T} 3$, and $\mathrm{T} 4$, respectively) and at the hip $(8.0,9.1,9.4$, and $8.5 \pm 0.49 \mathrm{~cm}$ for $\mathrm{T} 1, \mathrm{~T} 2, \mathrm{~T} 3$, and $\mathrm{T} 4$, respectively) increased with increasing intake of essential FA up to T3 before decreasing for calves fed T4 across sexes $(P=0.04$, quadratic effect). 
Table 4. Dry matter intake, BW gain, and feed efficiency (FE, kg of BW gain/kg of DMI) of preweaned male (M) and female (F) Holstein calves fed increasing amounts of linoleic and $\alpha$-linolenic acids

\begin{tabular}{|c|c|c|c|c|c|c|c|c|c|c|c|c|c|c|c|c|}
\hline \multirow[b]{3}{*}{ Measure } & \multicolumn{8}{|c|}{ Treatment $^{1}$} & \multirow[b]{3}{*}{ SEM } & \multicolumn{7}{|c|}{ Contrast, ${ }^{2} P$-value } \\
\hline & \multicolumn{2}{|c|}{$\mathrm{T} 1$} & \multicolumn{2}{|c|}{$\mathrm{T} 2$} & \multicolumn{2}{|c|}{ T3 } & \multicolumn{2}{|c|}{$\mathrm{T} 4$} & & \multirow[b]{2}{*}{$\mathrm{L}$} & \multirow[b]{2}{*}{ Q } & \multirow[b]{2}{*}{$\mathrm{Cb}$} & \multirow[b]{2}{*}{$\mathrm{S}$} & \multirow[b]{2}{*}{$\mathrm{L} \times \mathrm{S}$} & \multirow[b]{2}{*}{$\mathrm{Q} \times \mathrm{S}$} & \multirow[b]{2}{*}{$\mathrm{Cb} \times \mathrm{S}$} \\
\hline & M & $\mathrm{F}$ & $\mathrm{M}$ & $\mathrm{F}$ & M & $\mathrm{F}$ & $\mathrm{M}$ & $\mathrm{F}$ & & & & & & & & \\
\hline No. of calves & 7 & 14 & 9 & 13 & 9 & 13 & 9 & 14 & & & & & & & & \\
\hline \multicolumn{17}{|l|}{ Birth to $30 \mathrm{~d}$} \\
\hline Birth weight ${ }^{3} \mathrm{~kg}$ & 41.1 & 36.8 & 43.4 & 38.8 & 40.3 & 38.2 & 43.2 & 37.2 & 1.57 & 0.76 & 1.00 & 0.13 & $<0.01$ & 0.61 & 0.32 & 0.57 \\
\hline Milk replacer intake, $\mathrm{kg}$ of DM & 16.6 & 15.2 & 17.1 & 15.5 & 16.5 & 15.6 & 16.6 & 15.5 & 0.15 & 0.95 & 0.54 & 0.03 & $<0.01$ & 0.17 & 0.27 & 0.09 \\
\hline C18:2n-6 intake, $\mathrm{g}$ & 62 & 57 & 96 & 87 & 154 & 153 & 303 & 279 & 3.4 & $<0.01$ & 0.11 & 0.50 & $<0.01$ & 0.01 & 0.06 & 0.24 \\
\hline C18:3n-3 intake, g & 3.6 & 3.3 & 8.5 & 7.7 & 18.2 & 17.3 & 39.0 & 35.9 & 0.3 & $<0.01$ & 0.42 & 0.85 & $<0.01$ & $<0.01$ & 0.36 & 0.55 \\
\hline BW gain, $\mathrm{kg}$ & 2.75 & 2.62 & 5.26 & 3.09 & 2.80 & 3.30 & 2.70 & 3.44 & 0.54 & 0.66 & 0.44 & 0.01 & 0.49 & 0.07 & 0.98 & 0.02 \\
\hline $\mathrm{FE}$ & 0.16 & 0.17 & 0.31 & 0.20 & 0.17 & 0.21 & 0.17 & 0.22 & 0.03 & 0.84 & 0.44 & 0.01 & 0.95 & 0.11 & 0.96 & 0.04 \\
\hline \multicolumn{17}{|l|}{$31 \mathrm{~d}$ to weaning } \\
\hline Milk replacer intake, $\mathrm{kg}$ of $\mathrm{DM}$ & 19.8 & 18.1 & 20.4 & 18.2 & 20.0 & 18.3 & 19.8 & 18.3 & 0.19 & 0.88 & 0.24 & 0.17 & $<0.01$ & 0.17 & 0.67 & 0.13 \\
\hline $\mathrm{GM}^{4}$ intake, $\mathrm{kg}$ of DM & 16.3 & 13.7 & 13.4 & 13.3 & 16.1 & 13.5 & 15.6 & 13.3 & 1.66 & 0.92 & 0.88 & 0.30 & 0.11 & 0.82 & 0.95 & 0.40 \\
\hline BW gain, $\mathrm{kg}$ & 12.5 & 19.2 & 21.3 & 18.9 & 23.7 & 19.1 & 24.1 & 19.3 & 1.39 & 0.51 & 0.84 & 0.34 & $<0.01$ & 0.58 & 0.95 & 0.44 \\
\hline $\mathrm{FE}$ & 0.63 & 0.60 & 0.63 & 0.60 & 0.65 & 0.60 & 0.68 & 0.60 & 0.02 & 0.12 & 0.90 & 0.67 & $<0.01$ & 0.14 & 0.91 & 0.76 \\
\hline \multicolumn{17}{|l|}{ Birth to weaning } \\
\hline Final BW, kg & 68.3 & 59.5 & 68.7 & 59.7 & 68.6 & 60.1 & 68.9 & 60.4 & 1.35 & 0.61 & 0.91 & 0.92 & $<0.01$ & 0.88 & 0.95 & 0.90 \\
\hline Total DMI, kg & 52.8 & 47.0 & 52.6 & 46.9 & 52.6 & 47.3 & 52.1 & 47.1 & 1.7 & 0.94 & 0.97 & 0.52 & $<0.01$ & 0.97 & 0.91 & 0.62 \\
\hline BW gain, kg & 26.2 & 21.9 & 26.6 & 22.0 & 26.5 & 22.4 & 26.8 & 22.7 & 1.35 & 0.61 & 0.92 & 0.92 & $<0.01$ & 0.88 & 0.95 & 0.90 \\
\hline $\mathrm{FE}$ & 0.49 & 0.46 & 0.52 & 0.47 & 0.50 & 0.48 & 0.52 & 0.48 & 0.02 & 0.27 & 0.87 & 0.24 & $<0.01$ & 0.99 & 0.86 & 0.38 \\
\hline
\end{tabular}

${ }^{1}$ Targeted intakes of linoleic and $\alpha$-linolenic acids were 0.119 and 0.007 (T1), 0.187 and 0.017 (T2), 0.321 and 0.036 (T3), or 0.593 and 0.076 (T4) g/kg of BW ${ }^{0.75}$. Milk replacer was $\subseteq \quad$ the only feed offered during the first $30 \mathrm{~d}$ of life.

${ }^{2} P$-values for orthogonal contrasts of treatments, sex, and treatment by sex interactions: $\mathrm{L}=$ linear effect of treatment, $\mathrm{Q}=\mathrm{quadratic}$ effect of treatment, Cb $=$ cubic effect of 党 treatment, $\mathrm{S}=$ sex.

을 ${ }^{3}$ Birth weight deviations from the mean birth weight within each sex were covariates for all measures. Therefore, birth weight added to any later variable of gain will not give the @. expected BW.

₹ $\quad{ }^{4} \mathrm{GM}=$ grain mix. It was fed exclusively during the last $30 \mathrm{~d}$ of the preweaning period. 


\section{Metabolic and Hormonal Profiles}

Increasing consumption of SBO (from T1 to T3) resulted in decreasing $(P=0.02)$ mean concentrations of glucose in plasma of female calves before concentrations rebounded in calves fed T4, whereas that of male calves did not differ due to treatment (Table 5). Mean plasma concentrations of the anabolic hormones insulin and IGF-I did not differ due to treatments. Mean plasma concentrations of insulin were greater (2.7 vs. $2.0 \mathrm{ng} /$ $\mathrm{mL}, P<0.01)$ and that of IGF-1 tended to be greater (42.0 vs. $39.0 \mathrm{ng} / \mathrm{mL}, P=0.06)$ in male compared with female calves (Table 5), which coincides with greater DMI and BW gain for male compared with female calves (Table 4). Differences in plasma concentrations of anabolic metabolites and hormones are normally detected when calves experience different growth rates due to different intakes of nutrients (Smith et al., 2002).

Mean concentrations of plasma BHBA were lowest during the first $30 \mathrm{~d}$ of life $(<0.70 \mathrm{mg} / \mathrm{dL})$ before gradually increasing above $1.0 \mathrm{mg} / \mathrm{dL}$ after offering of dry feed was initiated (effect of age, $P<0.01$ ). Synthesis of BHBA by ruminal epithelium during absorption of butyric acid from microbial fermentation of concentrates likely accounted for the increase in blood concentration of BHBA after $30 \mathrm{~d}$ of age. Mean concentrations of plasma BHBA across sexes tended $(P=0.06)$ to decrease linearly as intake of essential FA increased $(0.88$, $0.80,0.76$, and $0.76 \mathrm{mg} / \mathrm{dL}$ for T1, T2, T3, and T4, respectively, Table 5). Polyunsaturated FA are known to activate and bind to peroxisome proliferator-activated receptor- $\alpha$ (PPAR- $\alpha)$ in liver. Once PPAR- $\alpha$ is activated, it stimulates $\beta$-oxidation and glucose metabolism as well as regulates cholesterol and lipoprotein metabolism to reduce dyslipidemia (Forman et al., 1997; Li and Chiang, 2009). Calves fed MR enriched in medium-chain FA compared with MR enriched in linoleic acid had greater circulating concentrations of BHBA within the first $3 \mathrm{~h}$ of feeding (Sato, 1994; Garcia et al., 2014b). Production of BHBA by hepatocytes from unweaned Holstein bull calves was less when incubated for $48 \mathrm{~h}$ with linoleic or $\alpha$-linolenic acid compared with C16:0 or C18:0 (Mashek and Grummer, 2003).

The effect of treatment on plasma concentrations of cholesterol was opposite to that of BHBA. Mean concentrations of plasma cholesterol increased quadratically as intake of essential FA increased (77.3, 82.5, 89.2, and $86.9 \mathrm{mg} / \mathrm{dL}$ for $\mathrm{T} 1, \mathrm{~T} 2, \mathrm{~T} 3$, and $\mathrm{T} 4$, respectively; $P=0.04$, Table 5). Similarly, feeding SBO compared with tallow or CCO in MR increased concentrations of plasma cholesterol in dairy calves (Stewart et al., 1978; Barrows et al., 1980). Although consumption of SFA usually results in increased circulating concentrations of cholesterol compared with consumption of unsaturated

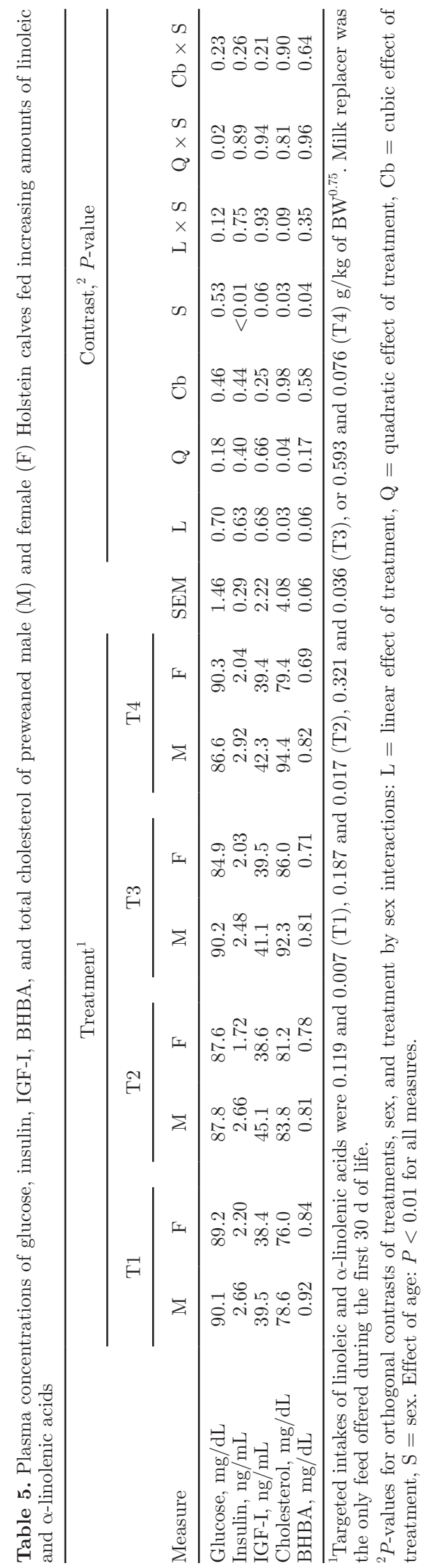


FA in humans, the intake of cholesterol is an important factor influencing this response (review by Goodnight et al., 1982). Because minimal, if any, cholesterol was consumed in the current study, this classical effect was not detected. The increased concentration of cholesterol in the current study due to increased intake of PUFA may simply reflect the preferential esterification of cholesterol esters with highly unsaturated FA.

\section{Incidence of Diarrhea and Diseases}

Treatment did not affect the incidence of pneumonia ( $18.1 \%$ incidence), navel infection (4.5\% incidence), or fever $(62.1 \%$ incidence). Based upon health scores and percentage of days with a health disorder, males were slightly healthier than females (Table 6). Mean scores for attitude were not affected by treatments. Severity of diarrhea increased at wk 2 of age $(P<0.01$, Figure 2$)$ and was accompanied by an increase in attitude score. Severity of diarrhea during the study tended $(P=0.07)$ to decrease linearly as intake of essential FA increased (Table 6). In addition, the age at first evidence of diarrhea tended $(P=0.10)$ to increase linearly from 7.0 to $7.6 \mathrm{~d}$ as the intake of essential FA increased (Table 6). Mean score and percentage of days with nasal discharge tended to increase $(P=0.10)$ or increased $(P=0.04)$, respectively, with increasing intake of essential FA before decreasing in calves fed $\mathrm{T} 4$.

\section{Hematocrit, Select Blood Cell Populations, and Neutrophil Function}

Mean values of hematocrit and blood cell populations (Table 7) were within the normal ranges for preweaned, healthy dairy calves (Brun-Hansen et al., 2006). Mean values for hematocrit and concentrations of platelets and lymphocytes were not affected by treatments. However, mean concentration of red blood cells tended $(P=0.10)$ to decrease linearly as intake of essential FA increased $\left(8.2,8.7,8.3\right.$, and $7.9 \times 10^{6} / \mu \mathrm{L}$ for $\mathrm{T} 1$, T2, $\mathrm{T} 3$, and T4, respectively, Table 7) which coincides with the tendency for increasing intake of essential FA to reduce diarrhea (Table 6). Increased concentrations of red blood cells as well as hematocrit are usually related to increased dehydration, often caused by increased incidence or severity of diarrhea.

Mean concentrations of blood neutrophils decreased $(P=0.04)$ between $\mathrm{T} 1$ and $\mathrm{T} 3$ before increasing at $\mathrm{T} 4\left(4.14,3.89,3.43\right.$, and $\left.4.45 \times 10^{3} / \mu \mathrm{L}\right)$ for female calves, whereas that of male calves were not different across treatments $\left(3.26,3.35,3.61\right.$, and $3.27 \times 10^{3} / \mu \mathrm{L}$, Table 7 ). If the progressively decreasing concentration of neutrophils detected in female calves fed T1 to T3 were due to increased migration from the blood to sites of inflammation, it would indicate that these calves were better able to mount an attack against infection; however, decreased production of neutrophils in bone marrow cannot be ruled out. Expression of receptors on neutrophil surfaces, which help regulate migration from the blood to injured tissues, was not evaluated. Male calves had $15 \%$ lower $(P \leq 0.01)$ circulating concentrations of neutrophils compared with female calves (3.37 vs. $\left.3.98 \times 10^{3} / \mu \mathrm{L}\right)$, which agrees with the better health indices reported in Table 6 for male calves. Perhaps the decreasing concentration of blood neutrophils in female calves fed T2 or T3 reflects improving health at the subclinical level.

Mean proportion of neutrophils undergoing phagocytosis tended $(P=0.09)$ to peak in calves fed T2 (62.1, 66.6, 64.2, and $62.8 \%$ for $\mathrm{T} 1, \mathrm{~T} 2, \mathrm{~T} 3$, and $\mathrm{T} 4$, respectively, Table 7). Ballou and DePeters (2008) also reported a curvilinear response of polymorphonuclear neutrophils from dairy calves fed increasing amounts of n-3 FA. In the current study, the proportion of neutrophils producing oxidative radicals did not differ with treatment (mean of 52.8\%). Mean fluorescence intensities for phagocytic activity and production of oxidative radicals were not affected by treatment but were greatest $(P<0.01)$ at $7 \mathrm{~d}$ of age. Female calves fed T2 or T3, who had lower circulatory concentrations of blood neutrophils due to potential increased migration to the sites of inflammation along with improved phagocytotic activity of these neutrophils, might be more efficient to resist pathogenic invasions. However, regardless of sex, the only positive health effect was a tendency for reduced severity of diarrhea when feeding increased amounts of essential FA.

\section{Circulating Concentration of Acute Phase Proteins}

Plasma concentrations of Hp followed the same pattern as that for fecal and attitude scores. Plasma Hp reached the greatest concentrations at $8 \mathrm{~d}$ of life, with calves fed $\mathrm{T} 1$ having the greatest concentration, and falling to nadir values from $15 \mathrm{~d}$ until the experiment ended (treatment by age interaction; $P=0.02$, Figure 3). Concentrations of $\mathrm{Hp}$ are absent in healthy calves but their concentrations increase dramatically even before the clinical signs of inflammatory disorders, such as diarrhea, appear (Gånheim et al., 2007; Cray et al., 2009). Calves fed T1 may have had a greater immune reaction to inflammation of the small intestine, suggesting that feeding more essential FA reduced the inflammatory response compared with feeding more mediumchain SFA, although feeding more PUFA also may have allowed a faster or greater resolution of diarrhea.

Mean plasma concentrations of ASP tended $(P=$ 0.08 , quadratic effect) to be lowest in calves fed T3 
Table 6. Health scores ${ }^{1}$ and percentage of days with poor attitude, fever, diarrhea, and nasal discharge of preweaned male (M) and female (F) Holstein calves fed increasing amounts of linoleic and $\alpha$-linolenic acids

\section{Treatment $^{2}$}

$\mathrm{T} 1$
$\mathrm{T} 2$

T3

Measure

Attitude score

Fecal score

Nasal discharge ${ }^{4}$

Rectal temp., ${ }^{\circ} \mathrm{C}$

Days to diarrhea

Days with: ${ }^{5} \%$

Poor attitude

Diarrhea

Nasal discharge

Fever, first 14

Fever, first 14 d

Attitude score scale: $0=$ responsive, $1=$ nonactive, $2=$ depressed, and $3=$ moribund. Feces score scale: $0=$ firm feces, no diarrhea; $1=$ soft feces, no diarrhea, $2=$ mild diarrhea, and $3=$ watery, severe diarrhea. Nasal score scale: $0=$ normal serous discharge, $1=$ small amount of unilateral cloudy discharge, $2=$ bilateral cloudy or excessive mucus discharge, and $3=$ copious bilateral mucopurulent discharge.

${ }^{2}$ Targeted intakes of linoleic and $\alpha$-linolenic acids were 0.119 and 0.007 (T1), 0.187 and 0.017 (T2), 0.321 and 0.036 (T3), or 0.593 and 0.076 (T4) g/kg of BW ${ }^{0.75}$. Milk replacer was the only feed offered during the first $30 \mathrm{~d}$ of life.

${ }^{3} P$-values for orthogonal contrasts of treatments, sex, and treatment by sex interactions: $\mathrm{L}=$ linear effect of treatment, $\mathrm{Q}=\mathrm{quadratic}$ effect of treatment, $\mathrm{Cb}=\mathrm{cubic}$ effect of treatment, $\mathrm{S}=$ sex. Effect of age: $P<0.01$ for all score measures.

${ }^{4}$ Treatment by age interaction: $P=0.08$.

${ }^{5}$ Percentage of days with health issue over a 60 -d period unless indicated. Poor attitude and nasal discharge if score $>0$, fever if temperature $\geq 39.5^{\circ} \mathrm{C}$, and diarrhea if score $>1$. 

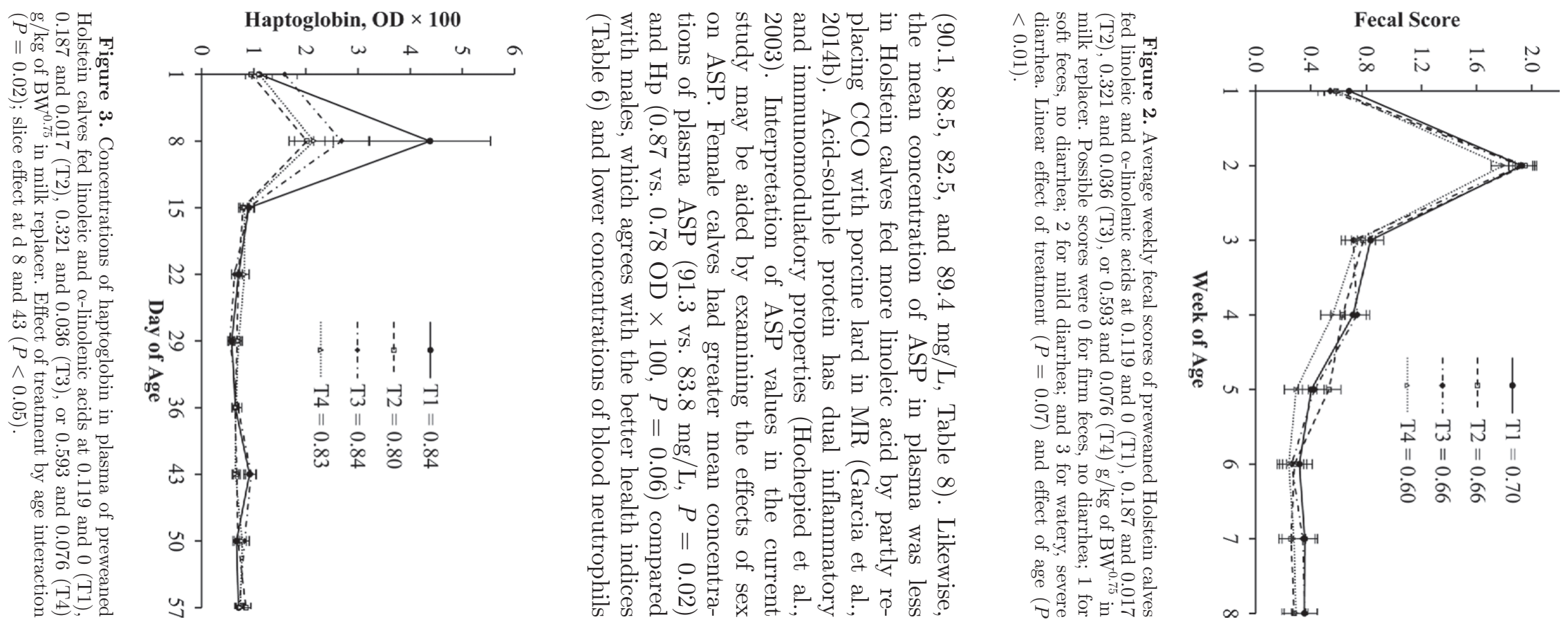

Table 7. Mean values of hematocrit and concentration of select blood cells, and phagocytosis, oxidative burst, and geometric mean fluorescence intensity (GMFI) of neutrophils in peripheral blood of preweaned male (M) and female (F) Holstein calves fed increasing amounts of linoleic and $\alpha$-linolenic acids

\begin{tabular}{|c|c|c|c|c|c|c|c|c|c|c|c|c|c|c|c|c|}
\hline \multirow[b]{3}{*}{ Measure } & \multicolumn{8}{|c|}{ Treatment $^{1}$} & \multirow[b]{3}{*}{ SEM } & \multicolumn{7}{|c|}{ Contrast, ${ }^{2} P$-value } \\
\hline & \multicolumn{2}{|c|}{$\mathrm{T} 1$} & \multicolumn{2}{|c|}{$\mathrm{T} 2$} & \multicolumn{2}{|c|}{$\mathrm{T} 3$} & \multicolumn{2}{|c|}{$\mathrm{T} 4$} & & \multirow[b]{2}{*}{$\mathrm{L}$} & \multirow[b]{2}{*}{$\mathrm{Q}$} & \multirow[b]{2}{*}{$\mathrm{Cb}$} & \multirow[b]{2}{*}{ S } & \multirow[b]{2}{*}{$\mathrm{L} \times \mathrm{S}$} & \multirow[b]{2}{*}{$\mathrm{Q} \times \mathrm{S}$} & \multirow[b]{2}{*}{$\mathrm{Cb} \times \mathrm{S}$} \\
\hline & $\mathrm{M}$ & $\mathrm{F}$ & $\mathrm{M}$ & $\mathrm{F}$ & M & $\mathrm{F}$ & $\mathrm{M}$ & $\mathrm{F}$ & & & & & & & & \\
\hline Hematocrit, \% & 33.1 & 32.3 & 32.8 & 32.9 & 32.3 & 32.2 & 32.1 & 32.1 & 0.65 & 0.23 & 0.80 & 0.62 & 0.62 & 0.74 & 0.69 & 0.65 \\
\hline Red blood cells, $10^{6} / \mu \mathrm{L}$ & 8.3 & 8.0 & 8.8 & 8.6 & 8.4 & 8.2 & 8.2 & 7.6 & 0.32 & 0.10 & 0.24 & 0.11 & 0.13 & 0.50 & 0.69 & 0.85 \\
\hline Neutrophils, $10^{3} / \mu \mathrm{L}$ & 3.26 & 4.14 & 3.35 & 3.89 & 3.61 & 3.43 & 3.27 & 4.45 & 0.31 & 0.57 & 0.43 & 0.94 & 0.01 & 0.55 & 0.04 & 0.71 \\
\hline Lymphocytes, $10^{3} / \mu \mathrm{L}$ & 4.11 & 4.74 & 4.67 & 4.71 & 4.63 & 4.73 & 4.60 & 4.47 & 0.28 & 0.95 & 0.36 & 0.55 & 0.41 & 0.28 & 0.60 & 0.45 \\
\hline $\begin{array}{l}\text { Platelets, } 10^{3} / \mu \mathrm{L} \\
\text { Phagocytosis }\end{array}$ & 488 & 521 & 527 & 515 & 561 & 415 & 518 & 447 & 49.8 & 0.48 & 0.84 & 0.56 & 0.15 & 0.27 & 0.13 & 0.66 \\
\hline$\%$ & 60.2 & 64.0 & 67.4 & 65.8 & 64.3 & 64.1 & 62.9 & 62.7 & 2.28 & 0.58 & 0.27 & 0.09 & 0.81 & 0.64 & 0.50 & 0.38 \\
\hline GMFI & 21.2 & 22.8 & 23.2 & 24.6 & 21.2 & 24.5 & 23.0 & 21.4 & 2.10 & 0.78 & 0.62 & 0.42 & 0.45 & 0.41 & 0.45 & 0.71 \\
\hline Oxidative burst & & & & & & & & & & & & & & & & \\
\hline$\%$ & 48.9 & 53.9 & 55.8 & 55.9 & 53.4 & 53.8 & 50.5 & 50.4 & 2.52 & 0.24 & 0.18 & 0.15 & 0.46 & 0.46 & 0.55 & 0.53 \\
\hline GMFI & 32.2 & 33.1 & 35.5 & 35.5 & 31.5 & 36.8 & 36.9 & 34.6 & 2.90 & 0.45 & 0.88 & 0.36 & 0.63 & 0.62 & 0.29 & 0.52 \\
\hline
\end{tabular}

$\varnothing \quad{ }_{\infty}^{1}$ Targeted intakes of linoleic and $\alpha$-linolenic acids were 0.119 and 0.007 (T1), 0.187 and 0.017 (T2), 0.321 and 0.036 (T3), or 0.593 and 0.076 (T4) g/kg of BW ${ }^{0.75}$. Milk replacer was $\mathbf{z}$ the only feed offered during the first $30 \mathrm{~d}$ of life.

$P$-values for orthogonal contrasts of treatments, sex, and treatment by sex interactions: $\mathrm{L}=$ linear effect of treatment, $\mathrm{Q}=$ quadratic effect of treatment, $\mathrm{Cb}=\mathrm{cubic}$ effect of treatment, $\mathrm{S}=$ sex. Effect of age: $P<0.01$ in phagocytosis and oxidative burst GMFI. 
(Table 7) for male calves. Therefore, lower ASP values with increasing intake of essential FA may reflect an improving immune status.

\section{Humoral and Cell-Mediated Immune Responses}

Neonates are born with a polarized and biased $\mathrm{T}$ helper (Th)-2 against Th-1 response, making them less able to mount a proper immune response to infectious agents. As reviewed by Adkins et al. (2004), a high number of naïve neonatal $\mathrm{CD} 4^{+} \mathrm{T}$ cells, fetal origin of these cells, and local environment can influence the changes in Th- 1 versus Th- 2 responses and therefore influence the responses of many other immune cells. Others have reported that neonates are born with high proportions of naïve $\mathrm{T}$ cells that can suppress immunoglobulin production (Clement et al., 1990) and also that neonates have a decreased capacity to produce Th1-type cytokines such as IFN- $\gamma$ (Wilson, 1986). Therefore, an overall change of polarized Th-2 response to a Th-1 response should enhance the cell-mediated and humoral immune responses of preweaned calves.

Lymphocytes from calves fed T2 demonstrated greater $(P=0.01)$ mean proliferation across all 3 measuring days of age $(14,28$, and $42 \mathrm{~d})$ as reflected in stimulation index means of 26.9, 39.1, 29.0, and 28.5 for T1, $\mathrm{T} 2$, T3, and T4, respectively (Table 8). Lymphocytes from calves fed T3 proliferated better than those from calves fed T1 only at the last sampling time of $42 \mathrm{~d}$ of age (Figure 4). Gorjão et al. (2007) reported that $25 \mu M$ linoleic acid stimulated IL-2-induced proliferation of human lymphocytes, preventing apoptosis and necrosis, but that greater concentrations of linoleic acid (75 and $100 \mu M$ ) reduced proliferation of lymphocytes compared with those in the control medium. Calder et al. (2002) reviewed studies that fed recommended amounts of $\alpha$-linolenic acid $(2 \mathrm{~g} / \mathrm{d})$ or amounts 6 times above recommendation and concluded that lymphocyte proliferation was reduced only when intake reached $13 \mathrm{~g} / \mathrm{d}$. Therefore, the amount of $\alpha$-linolenic acid fed in the current study should not have had a marked antiinflammatory effect that could lead to immunosuppression.

Concentration of TNF- $\alpha$ in supernatant of stimulated whole blood cells increased in a nonsignificant quadratic pattern $(337,373,424$, and $367 \mathrm{pg} / \mathrm{mL}$ for T1, T2, T3, and T4, respectively, $P=0.20$ ). Mean concentrations of IFN- $\gamma$ produced by lymphocytes in whole blood stimulated with LPS and PHA tended $(P=0.09)$ to be greater in male calves fed T3 (260, 357,411 , and $209 \mathrm{pg} / \mathrm{mL}$ for $\mathrm{T} 1, \mathrm{~T} 2$, T3, and $\mathrm{T} 4$, respectively), whereas lymphocytes from female calves fed T2 tended to produce more IFN- $\gamma$ compared with female calves fed the other treatments $(256,327,227$, and $265 \mathrm{pg} / \mathrm{mL}$ for $\mathrm{T} 1, \mathrm{~T} 2, \mathrm{~T} 3$, and $\mathrm{T} 4$, respectively; Table 8). As with lymphocyte proliferation, dietary intake of linoleic acid can be helpful to the immune system but overconsumption may have inhibitory effects. Stimulated peripheral blood mononuclear cells produced more IFN- $\gamma$ when Holstein calves were fed linoleic acid at 0.45 versus $0.14 \mathrm{~g} / \mathrm{kg}$ of $\mathrm{BW}^{0.75}$ in our previous study (Garcia et al., 2014b). The pattern of cytokine production is used to verify the predominant type of Th response. An increased concentration of IFN- $\gamma$ with constant or decreased production of IL-4 is indicative of Th-1 predominance (Chase et al., 2008). Greater mean production of IFN- $\gamma$ by calves fed T2 or T3 might indicate an improved ability of these calves to switch to a Th-1 response. Based on the proliferation index of lymphocytes and production of IFN- $\gamma$ by these proliferated lymphocytes, T3 for males and T2 for females appeared to provide optimal intakes of linoleic acid and $\alpha$-linolenic acid to induce proinflammatory activity of lymphocytes under these ex vivo conditions. However, this ex vivo-enhanced effect was not evidenced by corresponding improved health measures of male and female calves due to treatments, except for an overall effect of reduced diarrhea by greater intakes of essential FA.

In vivo challenge with ovalbumin, which is reported to be a good indicator of B-cell function in calves (Foote et al., 2007), resulted in greater $(P=0.04)$ concentrations of serum anti-OVA IgG in male calves fed T2 or T3 $(0.10,0.22,0.24$, and 0.13 OD; Table 8$)$, whereas female calves had similar mean serum concentrations across treatments $(0.17,0.18,0.18$, and 0.22 OD for T1, T2, T3, and T4, respectively; Table 8). The positive effect of T2 and T3 on ex vivo responsiveness of immune cells (greater production of IFN- $\gamma$ ) was verified by the in vivo measure of antibody production. Therefore, male calves appeared to have a more competent immune system due to enhanced cellular and humoral responses. Alternately, female calves did not increase production of anti-OVA IgG due to treatment although production of anti-OVA IgG in female calves was numerically greater than that in males when fed $\mathrm{T} 1(0.10$ vs. $0.17 \mathrm{OD})$ and $\mathrm{T} 4$ (0.13 vs. $0.22 \mathrm{OD})$. Based on these results, it seems that an enhanced humoral response in females is not limited by the intake of essential FA but an enhanced cell-mediated response requires that females be provided with increased supply of essential FA, such as that of T2.

A measure of DTH evaluates the ability of immune cells to infiltrate and accumulate into regions of antigen deposition. It is strictly a cell-mediated response, not an antibody-mediated response (Bernhagen et al., 1996). The use of PHA to induce a DTH response in cows resulted in the primary infiltration of eosinophils, 
Table 8. Mean concentrations of acute phase proteins in plasma, anti-ovalbumin (OVA) IgG in serum (optical density, OD), tumor necrosis factor $\alpha$ (TNF- $\alpha$ ), and IFN- $\gamma$ produced by whole blood cells stimulated with LPS and phytohemagglutinin, and proliferation of whole blood cells by incubation with concanavalin A in preweaned male (M) and female (F) Holstein calves fed increasing amounts of linoleic and $\alpha$-linolenic acids

\begin{tabular}{|c|c|c|c|c|c|c|c|c|c|c|c|c|c|c|c|c|}
\hline \multirow[b]{3}{*}{ Measure } & \multicolumn{8}{|c|}{ Treatment $^{1}$} & \multirow[b]{3}{*}{ SEM } & \multicolumn{7}{|c|}{ Contrast, ${ }^{2} P$-value } \\
\hline & \multicolumn{2}{|c|}{$\mathrm{T} 1$} & \multicolumn{2}{|c|}{$\mathrm{T} 2$} & \multicolumn{2}{|c|}{ T3 } & \multicolumn{2}{|c|}{$\mathrm{T} 4$} & & \multirow[b]{2}{*}{$\mathrm{L}$} & \multirow[b]{2}{*}{ Q } & \multirow[b]{2}{*}{$\mathrm{Cb}$} & \multirow[b]{2}{*}{ S } & \multirow[b]{2}{*}{$\mathrm{L} \times \mathrm{S}$} & \multirow[b]{2}{*}{$\mathrm{Q} \times \mathrm{S}$} & \multirow[b]{2}{*}{$\mathrm{Cb} \times \mathrm{S}$} \\
\hline & M & $\mathrm{F}$ & M & $\mathrm{F}$ & M & $\mathrm{F}$ & M & $\mathrm{F}$ & & & & & & & & \\
\hline Haptoglobin ${ }^{3}$ & 0.82 & 0.86 & 0.75 & 0.84 & 0.77 & 0.90 & 0.77 & 0.88 & 0.07 & 0.94 & 0.91 & 0.49 & 0.06 & 0.64 & 0.62 & 0.84 \\
\hline $\begin{array}{l}\mathrm{ASP},{ }^{4} \mathrm{mg} / \mathrm{L} \\
\text { Cell proliferation }\end{array}$ & 84.6 & 95.6 & 80.6 & 96.5 & 81.2 & 83.9 & 88.8 & 90.0 & 4.49 & 0.97 & 0.08 & 0.61 & 0.02 & 0.17 & 0.81 & 0.28 \\
\hline Control & 0.50 & 0.52 & 0.56 & 0.56 & 0.55 & 0.58 & 0.59 & 0.65 & 0.08 & 0.23 & 0.81 & 0.65 & 0.71 & 0.75 & 0.93 & 0.87 \\
\hline Stimulated & 12.8 & 14.7 & 23.5 & 20.4 & 14.0 & 18.8 & 16.2 & 19.0 & 2.83 & 0.67 & 0.44 & 0.01 & 0.33 & 0.63 & 0.71 & 0.22 \\
\hline Stim. index ${ }^{6}$ & 25.5 & 28.4 & 41.7 & 36.5 & 25.3 & 32.7 & 27.6 & 29.4 & 4.47 & 0.47 & 0.51 & 0.01 & 0.47 & 0.80 & 0.61 & 0.22 \\
\hline TNF- $\alpha, \mathrm{pg} / \mathrm{mL}$ & 311 & 362 & 424 & 321 & 457 & 390 & 345 & 389 & 64.2 & 0.72 & 0.20 & 0.94 & 0.68 & 0.66 & 0.26 & 0.40 \\
\hline IFN- $\gamma, \mathrm{pg} / \mathrm{mL}$ & 260 & 256 & 357 & 327 & 411 & 227 & 209 & 265 & 66.4 & 0.38 & 0.19 & 0.38 & 0.39 & 0.62 & 0.09 & 0.57 \\
\hline Anti-OVA IgG, OD & 0.10 & 0.17 & 0.22 & 0.18 & 0.24 & 0.18 & 0.13 & 0.22 & 0.04 & 0.58 & 0.08 & 0.33 & 0.71 & 0.47 & 0.04 & 0.47 \\
\hline
\end{tabular}

${ }^{1}$ Targeted intakes of linoleic and $\alpha$-linolenic acids were 0.119 and 0.007 (T1), 0.187 and 0.017 (T2), 0.321 and 0.036 (T3), or 0.593 and 0.076 (T4) g/kg of BW ${ }^{0.75}$.Milk replacer wa the only feed offered during the first $30 \mathrm{~d}$ of life

${ }^{2} P$-value for orthogonal contrasts of treatments, sex, and treatment by sex interactions: $\mathrm{L}=$ linear effect of treatment, $\mathrm{Q}=\mathrm{quadratic}$ effect of treatment, $\mathrm{Cb}=\mathrm{cubic}$ effect of treatment, $\mathrm{S}=$ sex. Effect of age was always significant.

${ }^{3}$ Haptoglobin (optical density $\times 100$ ), treatment by age: $P=0.02$.

Acid-soluble protein, treatment by age: $P<0.01$

${ }^{5}$ Proliferation is expressed as 1,000 counts per minute of thymidine incorporation. 


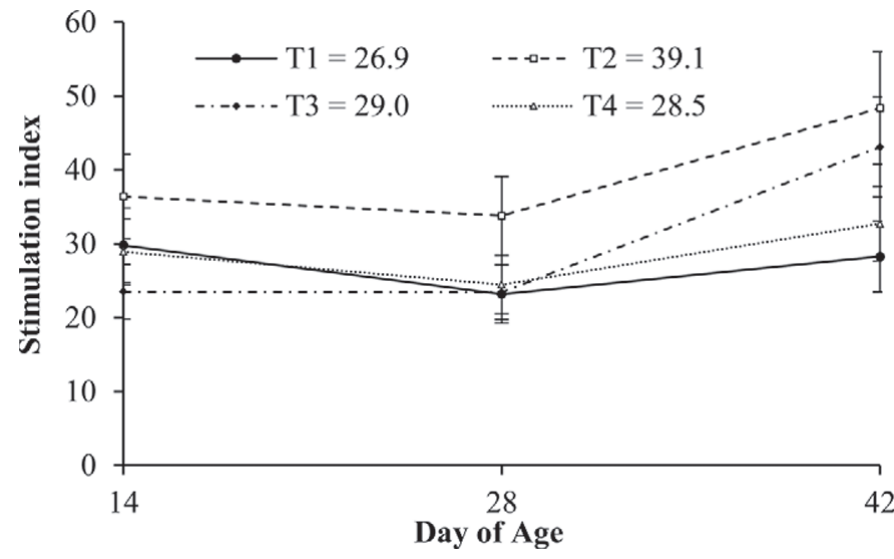

Figure 4. Stimulation index is calculated as the number of whole blood lymphocytes proliferated by LPS and phytohemagglutinin stimulation divided by the number of lymphocytes proliferated without stimulation of Holstein calves fed $\mathrm{C} 18$ linoleic and $\alpha$-linolenic acids at 0.119 and 0 (T1), 0.187 and 0.017 (T2), 0.321 and 0.036 (T3), or 0.593 and $0.076(\mathrm{~T} 4) \mathrm{g} / \mathrm{kg}$ of $\mathrm{BW}^{0.75}$ respectively, in milk replacer. Cubic effect of treatment $(P=0.01)$ and effect of age $(P<0.01)$.

macrophages, and neutrophils, but not lymphocytes (Hernández et al., 2005). Not all calves were responsive to an intradermal injection of PHA. Proportions of calves responsive to PHA challenge were 90 and $79 \%$ at 30 and $60 \mathrm{~d}$ of age, respectively. The risk ratio analysis at 30 and $60 \mathrm{~d}$ of age indicated that treatments 2,3 , or $4 \mathrm{did}$ not differ from $\mathrm{T} 1(P>0.40)$ in the number of calves responsive to PHA challenge. A second analysis that only included responsive calves (calves having an increase in skin-fold thickness after PHA injection at any of the 3 measuring times postinjection) was conducted. At $30 \mathrm{~d}$ of age, mean skin-fold thickness across hours postchallenge increased $(P=0.03)$ linearly with increasing intake of essential FA $(7.7,11.0,14.4$, and $15.6 \%$ for T1, T2, T3, and T4, respectively; Figure 5A). When PHA was injected at $60 \mathrm{~d}$ of age, skin thickness tended $(P=0.08)$ to increase linearly with increased intake of essential FA across hours postinjection. Mean increases were $6.9,12.3$, 13.5, and $15.4 \%$ for $\mathrm{T} 1, \mathrm{~T} 2, \mathrm{~T} 3$, and $\mathrm{T} 4$, respectively (Figure 5B). However, the treatment response to PHA challenge differed between sexes at $30 \mathrm{~d}$ of age (sex by cubic treatment interaction, $P=0.01$ ). At $30 \mathrm{~d}$ of age, male calves fed T2, T3, or T4 responded similarly and to a greater degree than control calves $(6.5,16.3,11.8$, and $15.6 \%$ ), whereas female calves fed $\mathrm{T} 3$ and $\mathrm{T} 4$ responded similarly and to a greater degree than control calves $(8.8,5.7,17.0$, and $15.6 \%)$. Therefore, regardless of sex, increasing intake of essential FA, potentially mediated by the proinflammatory effect of linoleic acid, resulted in increased recruitment and accumulation of mononuclear cells in response to a PHA.

What is the optimum feeding rate of essential FA for unweaned Holstein calves based upon the results
A)

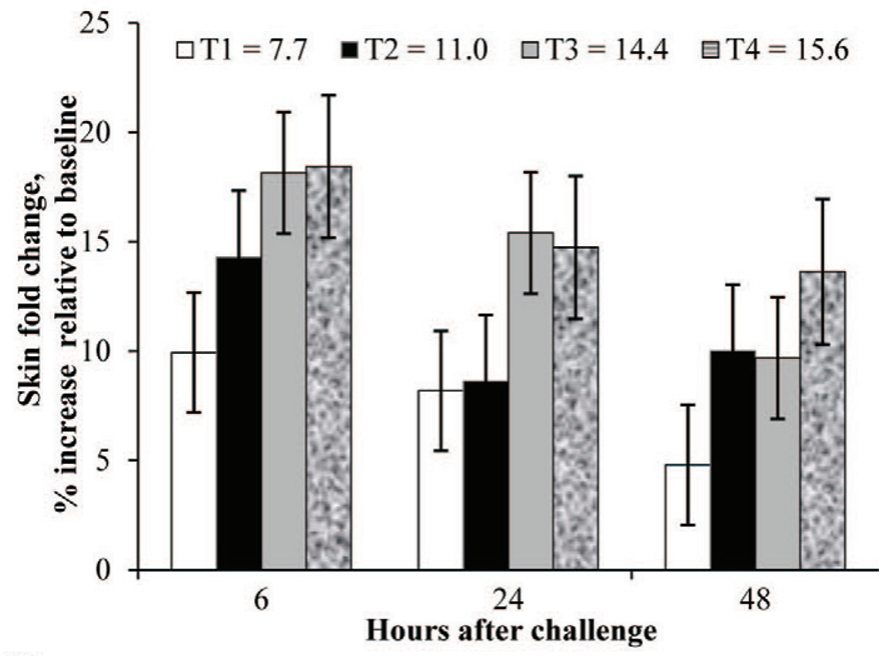

B)

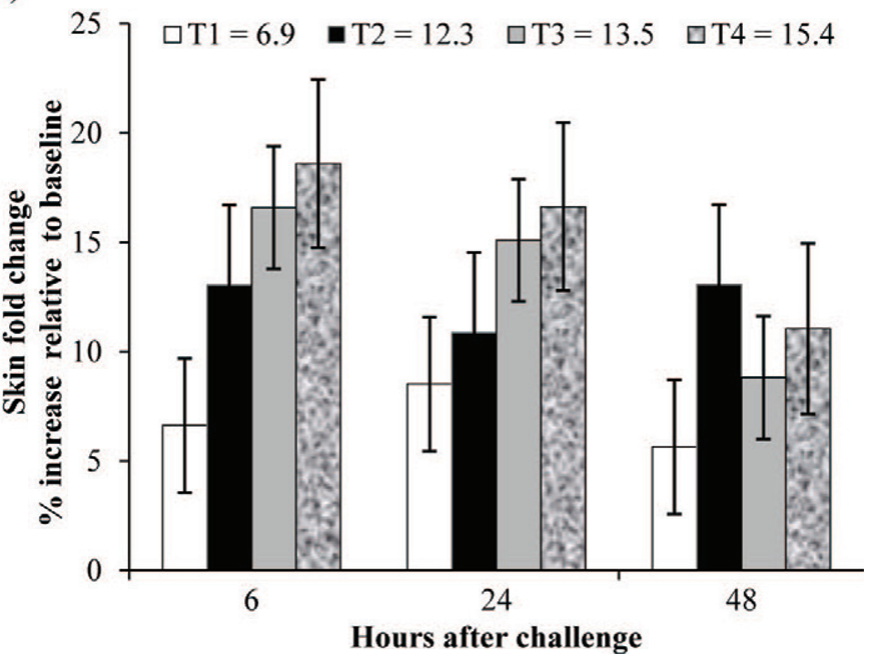

Figure 5. Proportional change in skin-fold thickness after phytohemagglutinin injection in responsive Holstein calves fed linoleic and $\alpha$-linolenic acids at 0.119 and 0 (T1), 0.187 and 0.017 (T2), 0.321 and 0.036 (T3), or 0.593 and 0.076 (T4) $\mathrm{g} / \mathrm{kg}$ of $\mathrm{BW}^{0.75}$ in milk replacer. (A) Injection at $30 \mathrm{~d}$ of age; linear effect of treatment $(P=0.03)$ and effect of hours postchallenge $(P<0.01)$. (B) Injection at $60 \mathrm{~d}$ of age; linear effect of treatment $(P=0.08)$ and effect of hours postchallenge $(P<0.01)$.

of this study? Many measurements, such as BW gain, FE, skeletal growth, concentration, and phagocytosis of neutrophils in blood, plasma concentrations of acute phase proteins, and proliferation and production of IFN- $\gamma$ by blood lymphocytes, appeared to be optimized when calves were assigned to T2 $(0.187$ and $0.017 \mathrm{~g}$ of linoleic and $\alpha$-linolenic acids per $\mathrm{kg}$ of $\mathrm{BW}^{0.75}$, respectively) or to T3 (0.321 and $0.036 \mathrm{~g}$ of linoleic and $\alpha$-linolenic acids per $\mathrm{kg}$ of $\mathrm{BW}^{0.75}$, respectively). This would represent an intake of 3 to $5 \mathrm{~g} / \mathrm{d}$ of linoleic acid and 0.3 to $0.6 \mathrm{~g} / \mathrm{d}$ of $\alpha$-linolenic acid for a $40-\mathrm{kg}$ calf. In 
addition to MR, dairy calves are offered a grain-based mixture during their preweaning period in nearly all management systems. Intake of grain during the first week of life is negligible so that MR supplies almost all of the nutrients consumed, meaning that the nutrient composition of MR is critically important. If during the second week of life, calves consumed, on average, $100 \mathrm{~g}$ of grain mix (DM basis), calculated intake of linoleic and $\alpha$-linolenic acids from the grain mix would approximate 1.0 and $0.09 \mathrm{~g} / \mathrm{d}$, respectively based upon the FA concentration and profile of the grain mix in Tables 2 and 3. These amounts consumed are $30 \%$, at best, of the calves' estimated essential FA requirement from this study. A calf consuming $500 \mathrm{~g}$ of grain DM daily ( $\geq 3$ wk of age; Davis and Drackley, 1998) likely would be consuming almost the required daily amounts of essential FA from the grain mix. As the calf grows, its requirement for essential FA also increases. Considering that dairy calves managed under typical industry conditions attain greater BW gains than did calves in the current study, the requirement of essential FA may be greater than documented here and the calf would need to rely upon both MR and grain mix to consume sufficient amounts of essential FA.

The intake of linoleic acid by calves fed T3 was intermediate of that recommended for growing female and male rats $(0.212$ and $0.551 \mathrm{~g}$ of linoleic acid per $\mathrm{kg}$ of $\mathrm{BW}^{0.75}$, respectively; NRC, 1995) and that of $\alpha$-linolenic acid was about $50 \%$ of the intake recommended for young women (DRI, 2005). Some responses such as mean fecal score, number of days to first diarrhea, hypersensitivity of skin to PHA injections, and ADG (females only) were improved at the greatest feeding rate of the essential FA. The concentration of C20:3n-9 in liver decreased linearly with increasing intake of essential FA, becoming almost undetectable when $\mathrm{T} 4$ was fed. Synthesis of C20:3n-9 from C18:1n-9 is uncommon unless essential FA are present in very low amounts. Under such deficiency conditions, competition among n-9, n- 6 , and n- 3 FA for $\Delta^{6}$ - and $\Delta^{5}$-desaturase enzymes is greatly reduced, allowing C20:3n-9 to be synthesized from C18:1n-9 (Cook, 1996). Ratios of C20:3n-9 to C20:4n-6 in liver tissue at $30 \mathrm{~d}$ of age was $<0.2$, indicating that calves in the current study were not clinically deficient in linoleic acid based on traditional guidelines. Whether or not this ratio is applicable to growing ruminants, growth and immunity of preweaned dairy calves benefited from an increasing supply of essential FA to a CCO-based MR.

\section{CONCLUSIONS}

Partial replacement of CCO with SBO in MR formulation increased daily intake of linoleic and $\alpha$-linolenic acids by preweaned Holstein calves. As a result, hepatic concentrations of these 2 essential FA also increased linearly and that of C20:3n-9 decreased linearly. During the first $30 \mathrm{~d}$ of life, when MR was the only feedstuff consumed, ADG and FE were optimized when males were fed 0.187 and $0.017 \mathrm{~g}$ of linoleic and $\alpha$-linolenic acids per $\mathrm{kg}$ of $\mathrm{BW}^{0.75}$, respectively, whereas ADG of female calves tended to increase linearly with increasing intake of linoleic and $\alpha$-linolenic acids up to 0.593 and $0.076 \mathrm{~g}$ of linoleic and $\alpha$-linolenic acids per $\mathrm{kg}$ of $\mathrm{BW}^{0.75}$, respectively. Over the $60-\mathrm{d}$ preweaning period, skeletal growth was improved across sexes as intake of essential FA increased to 0.321 and $0.036 \mathrm{~g}$ of linoleic and $\alpha$-linolenic acids per $\mathrm{kg}$ of $\mathrm{BW}^{0.75}$, respectively. Several measures of immune function were increased when T2 or T3 were fed. Based upon growth performance and immune responses, unweaned Holstein calves benefited from consuming 3 to $5 \mathrm{~g} / \mathrm{d}$ of linoleic acid and 0.3 to $0.6 \mathrm{~g} / \mathrm{d}$ of $\alpha$-linolenic acid.

\section{ACKNOWLEDGMENTS}

The help of the entire staff at the University of Florida Dairy Research Unit is appreciated deeply. Thanks to Nishanth Tharayil from Clemson University (Clemson, SC) for analyzing liver tissue for FA. The National Institute of Food and Agriculture Division of the USDA (Washington, DC; award 2009-34135-20053) is acknowledged for partial funding of the study.

\section{REFERENCES}

Adkins, B., S. Marshall-Clarke, and C. Leclerc. 2004. Neonatal adaptive immunity comes of age. Nat. Rev. Immunol. 4:553-564.

Anderson, G. J., and W. E. Connor. 1989. On the demonstration of omega-3 essential-fatty-acid deficiency in humans. Am. J. Clin. Nutr. 49:585-587.

Badinga, L., R. J. Collier, W. W. Thatcher, C. J. Wilcox, H. H. Head, and F. W. Bazer. 1991. Ontogeny of hepatic bovine growth hormone receptors in cattle. J. Anim. Sci. 69:1925-1934.

Ballou, M. A., G. D. Cruz, W. Pitroff, D. H. Keisler, and E. J. DePeters. 2008. Modifying the acute phase response of Jersey calves by supplementing milk replacer with omega-3 fatty acids from fish oil. J. Dairy Sci. 91:3478-3487.

Ballou, M. A., and E. J. DePeters. 2008. Supplementing milk replacer with omega-3 fatty acids from fish oil on immunocompetence and health of Jersey calves. J. Dairy Sci. 91:3488-3500.

Barrows, K. K., T. R. Heeg, A. D. McGilliard, M. J. Richard, and N. L. Jacobson. 1980. Effect of type of dietary fat on plasma and tissue cholesterol of calves. J. Nutr. 110:335-342.

Bernhagen, J., M. Bacher, T. Calandra, C. N. Metz, S. B. Doty, T. Donelly, and R. Bucala. 1996. An essential role for macrophage migration inhibitory factor in the tuberculin delayed-type hypersensitivity reaction. J. Exp. Med. 183:277-282.

Brun-Hansen, H. C., A. H. Kampen, and A. Lund. 2006. Hematological values in calves during the first six months of life. Vet. Clin. Pathol. 35:182-187.

Burr, G. O., and M. M. Burr. 1930. On the nature and role of the fatty acids essential in nutrition. J. Biol. Chem. 86:587-621.

Calder, P. C. 2006. Polyunsaturated fatty acids and inflammation. Prostaglandins Leukot. Essent. Fatty Acids 75:197-202. 
Calder, P. C. 2008. The relationship between the fatty acid composition of immune cells and their function. Prostaglandins Leukot. Essent. Fatty Acids 79:101-108.

Calder, P. C., P. Yaqoob, F. Thies, F. A. Wallace, and E. A. Miles. 2002. Fatty acids and lymphocyte functions. Br. J. Nutr. 87(Suppl. 1):S31-S48.

Chase, C. C. L., D. J. Hurley, and A. J. Reber. 2008. Neonatal immune development in the calf and its impact on vaccine response. Vet. Clin. North Am. Food Anim. Pract. 24:87-104.

Clement, L. T., P. E. Vink, and G. E. Bradley. 1990. Novel immunoregulatory functions of phenotypically distinct subpopulations of CD4+ cells in the human neonate. J. Immunol. 145:102-108.

Cook, H. W. 1996. Fatty acid desaturation and chain elongation in eukaryotes. Chapter 5 in Biochemistry of Lipids, Lipoproteins and Membranes. Vance, D. E., and J. Vance, eds. Elsevier Sci. Amsterdam, The Netherlands.

Cray, C., J. Zaias, and N. H. Altman. 2009. Acute phase response in animals: A review. Comp. Med. 59:517-526.

Cunnane, S. C., and P. Guesnet. 2011. Linoleic acid recommendations-A house of cards. Prostaglandins Leukot. Essent. Fatty Acids 85:399-402.

Cunningham, H. M., and J. K. Loosli. 1954. The effect of fat-free diets on lambs and goats. J. Anim. Sci. 13:265-273.

Davis, C. L., and J. K. Drackley. 1998. Page 295 in The Development, Nutrition, and Management of the Young Calf. Iowa State Univ. Press, Ames.

DRI. 2005. Dietary Reference Intakes for Energy, Carbohydrate, Fiber, Fat, Fatty acids, Cholesterol, Protein, and Amino Acids (Macronutrients). The National Academy Press, Washington, DC.

Foote, M. R., B. J. Nonnecke, D. C. Beitz, and W. R. Waters. 2007. High growth rate fails to enhance adaptive immune responses of neonatal calves and is associated with reduced lymphocyte viability. J. Dairy Sci. 90:404-417.

Forman, B. M., C. Chen, and R. M. Evans. 1997. Hypolipodemic drugs, polyunsaturated fatty acids, and eicosanoids are ligands for peroxisome proliferator-activated receptors $\alpha$ and $\delta$. Proc. Natl. Acad. Sci. USA 94:4312-4317.

Gånheim, C., S. Alenius, and K. P. Waller. 2007. Acute phase proteins as indicators of calf herd health. Vet. J. 173:645-651.

Garcia, M., L. F. Greco, M. G. Favoreto, R. S. Marsola, L. T. Martins, R. S. Bisinotto, J. H. Shin, A. L. Lock, E. Block, W. W. Thatcher, J. E. P. Santos, and C. R. Staples. 2014a. Effect of supplementing fat to pregnant nonlactating cows on colostral fatty acid profile and passive immunity of the newborn calf. J. Dairy Sci. 97:392-405.

Garcia, M., L. F. Greco, M. G. Favoreto, R. S. Marsola, D. Wang, J. H. Shin, E. Block, W. W. Thatcher, J. E. P. Santos, and C. R. Staples. 2014b. Effect of supplementing essential fatty acids to pregnant nonlactating Holstein cows and their preweaned calves on calf performance, immune response, and health. J. Dairy Sci. 97:5045-5064.

Gochman, N., and J. M. Schmitz. 1972. Application of a new peroxide indicator reaction to the specific automated determination of glucose with glucose oxidase. Clin. Chem. 18:943-950.

Godden, S. 2008. Colostrum management for dairy calves. Vet. Clin. North Am. Food Anim. Pract. 24:19-39.

Goodnight, S. H. Jr., W. S. Harris, W. E. Connor, and D. R. Illingworth. 1982. Polyunsaturated fatty acids, hyperlipidemia, and thrombosis. Arteriosclerosis 2:87-113.

Gorjão, R., M. F. Cury-Boaventura, T. M. de Lima, and R. Curi. 2007. Regulation of human lymphocyte proliferation by fatty acids. Cell Biochem. Funct. 25:305-315.

Hernández, A., J. A. Yager, B. N. Wilkie, K. E. Leslie, and B. A. Mallard. 2005. Evaluation of bovine cutaneous delayed-type hypersensitivity to various test antigens and a mitogen using several adjuvants. Vet. Immunol. Immunopathol. 104:45-58.

Hochepied, T., F. G. Berger, and H. Baumann. 2003. a1-Acid glycoprotein: An acute phase protein with inflammatory and immunomodulating properties. Cytokine Growth Factor Rev. 14:25-34.

Holman, R. T. 1978. How essential are essential fatty acids? J. Am. Oil Chem. Soc. 55:774A-781A.
Hulbert, L. E., C. J. Cobb, J. A. Carroll, and M. A. Ballou. 2011. Effects of changing milk replacer feedings from twice to once daily on Holstein calf innate immune responses before and after weaning. J. Dairy Sci. 94:2557-2565.

Innis, S. M. 2007. Dietary (n-3) fatty acids and brain development. J. Nutr. 137:855-859.

Jenkins, K. J., J. K. Kramer, and D. B. Emmons. 1986. Effect of lipids in milk replacers on calf performance and lipids in blood plasma, liver, and perirenal fat. J. Dairy Sci. 69:447-459.

Jenkins, K. J., and J. K. G. Kramer. 1986. Influence of low linoleic and linolenic acids in milk replacer on calf performance and lipids in blood plasma, heart, and liver. J. Dairy Sci. 69:1374-1386.

Jenkins, K. J., J. K. G. Kramer, F. D. Sauer, and D. B. Emmons. 1985. Influence of triglycerides and free fatty acids in milk replacers on calf performance, blood plasma, and adipose lipids. J. Dairy Sci. 68:669-680.

Kaur, G., D. Cameron-Smith, M. Garg, and A. J. Sinclair. 2011. Docosapentaenoic acid (22:5n-3): A review of its biological effects. Prog. Lipid Res. 50:28-34.

Lambert, M. R., N. L. Jacobson, R. S. Allen, and J. H. Zaletel. 1954. Lipid deficiency in the calf. J. Nutr. 52:259-272.

Li, T., and J. Y. Chiang. 2009. Regulation of bile acid and cholesterol metabolism by PPARs. PPAR Res. 2009:501739. http://dx.doi. org $/ 10.1155 / 2009 / 501739$.

Makimura, S., and N. Suzuki. 1982. Quantitative determination of bovine serum haptoglobin and its elevation in some inflammatory diseases. Jpn. J. Vet. Sci. 44:15-21.

Mallard, B. A., L. C. Wagter, M. J. Ireland, and J. C. M. Dekkers. 1997. Effects of growth hormone, insulin-like growth factor I, and cortisol on periparturient antibody response profiles of dairy cattle. Vet. Immunol. Immunopathol. 60:61-76.

Marsh, W. H., B. Fingerhut, and H. Miller. 1965. Automated and manual direct methods for the determination of blood urea. Clin. Chem. 11:624-627.

Martinez, N., C. A. Risco, F. S. Lima, R. S. Bisinotto, L. F. Greco, E. S. Ribeiro, F. Maunsell, K. Galvão, and J. E. P. Santos. 2012. Evaluation of peripartal calcium status, energetic profile, and neutrophil function in dairy cows at low or high risk of developing uterine disease. J. Dairy Sci. 95:7158-7172.

Mashek, D. G., and R. R. Grummer. 2003. Effects of long chain fatty acids on lipid and glucose metabolism in monolayer cultures of bovine hepatocytes. J. Dairy Sci. 86:2390-2396.

Mead, J. F., and W. H. Slaton Jr.. 1956. Metabolism of essential fatty acids. III. Isolation of 5,8,11- eicosatrienoic acid from fat-deficient rats. J. Biol. Chem. 219:705-709.

Mohrhauer, H., and R. T. Holman. 1963. The effect of dose level of essential fatty acids upon fatty acid composition of the rat liver. J. Lipid Res. 4:151-159.

Neuringer, M., G. J. Anderson, and W. E. Connor. 1988. The essentiality of n-3 fatty acids for the development and function of the retina and brain. Annu. Rev. Nutr. 8:517-541.

Noble, R. C., M. L. Crouchman, D. M. Jenkinson, and J. H. Moore. 1975. Relationship between lipids in plasma and skin secretions of neonatal calf with particular reference to linoleic acid. Lipids 10:128-133.

Noble, R. C., W. Steele, and J. H. Moore. 1972. The metabolism of linoleic acid by the young lamb. Br. J. Nutr. 27:503-508.

NRC. 1995. Nutrient Requirements for Laboratory Animals. 4th rev. ed. Natl. Acad. Sci., Washington, DC.

NRC. 2001. Nutrient Requirements of Dairy Cattle. 7th rev. ed. Natl. Acad. Sci., Washington, DC.

O'Fallon, J. V., J. R. Busboom, M. L. Nelson, and C. T. Gaskins. 2007. A direct method for fatty acid methyl ester synthesis: Application to wet meat tissues, oils and feedstuffs. J. Anim. Sci. 85:1511-1521.

Pudelkewicz, C., J. Seufert, and R. T. Holman. 1968. Requirement of the female rat for linoleic and linolenic acids. J. Nutr. 94:138-146.

Sato, H. 1994. Plasma ketone levels in neonatal calves fed medium chain triglycerides in milk. J. Vet. Med. Sci. 56:781-782.

Schmitz, G., and J. Ecker. 2008. The opposing effects of n-3 and n-6 fatty acids. Prog. Lipid Res. 47:147-155. 
Sklan, D., R. Volcani, and P. Budowski. 1972. Effects of diets low in fat or essential fatty acids on the fatty acid composition of blood lipids of calves. Br. J. Nutr. 27:365-374.

Smith, J. M., M. E. Van Amburgh, M. C. Diaz, M. C. Lucy, and D. E. Bauman. 2002. Effect of nutrient intake on the development of the somatotropic axis and its responsiveness to GH in Holstein bull calves. J. Anim. Sci. 80:1528-1537.

Smits, E., C. Burvenich, and R. Heyneman. 1997. Simultaneous flow cytometric measurement of phagocytotic and oxidative burst activity of polymorphonuclear leukocytes in whole bovine blood. Vet. Immunol. Immunopathol. 56:259-269.
Stewart, J. W., K. D. Wiggers, N. L. Jacobson, and P. J. Berger. 1978. Effect of various triglycerides on blood and tissue cholesterol of calves. J. Nutr. 108:561-566.

Tyler, J. W., D. D. Hancock, S. M. Parish, D. E. Rea, T. E. Besser, S. G. Sanders, and L. K. Wilson. 1996. Evaluation of 3 assays for failure of passive transfer in calves. J. Vet. Intern. Med. 10:304-307.

Wilson, C. B. 1986. Immunologic basis for increased susceptibility of the neonate to infection. J. Pediatr. 108:1-12. 